\title{
Cellular Prion Protein Mediates the Disruption of Hippocampal Synaptic Plasticity by Soluble Tau In Vivo
}

\author{
Tomas Ondrejcak, ${ }^{1}$ Igor Klyubin, ${ }^{1}$ Q Grant T. Corbett, ${ }^{2}$ Graham Fraser, ${ }^{3}$ Wei Hong, ${ }^{2}$ Alexandra J. Mably, ${ }^{2}$ \\ Matthew Gardener, ${ }^{4}$ Jayne Hammersley, ${ }^{4}$ Michael S. Perkinton, ${ }^{3}$ Andrew Billinton, ${ }^{3}{ }^{\circ}$ Dominic M. Walsh, ${ }^{2}$ \\ and Michael J. Rowan ${ }^{1}$ \\ ${ }^{1}$ Department of Pharmacology and Therapeutics and Institute of Neuroscience, Trinity College Dublin, Dublin 2, Ireland, ${ }^{2}$ Laboratory for \\ Neurodegenerative Research, Ann Romney Center for Neurologic Diseases, Brigham and Women's Hospital, and Harvard Medical School, Boston, \\ Massachusetts $02115,{ }^{3}$ Neuroscience, IMED Biotech Unit, AstraZeneca, Cambridge, CB21 6GH, United Kingdom, and ${ }^{4}$ Antibody Discovery and Protein \\ Engineering, MedImmune, Granta Park, Cambridge, CB21 6GH, United Kingdom
}

Intracellular neurofibrillary tangles (NFTs) composed of tau protein are a neuropathological hallmark of several neurodegenerative diseases, the most common of which is Alzheimer's disease (AD). For some time NFTs were considered the primary cause of synaptic dysfunction and neuronal death, however, more recent evidence suggests that soluble aggregates of tau are key drivers of disease. Here we investigated the effect of different tau species on synaptic plasticity in the male rat hippocampus in vivo. Intracerebroventricular injection of soluble aggregates formed from either wild-type or P301S human recombinant tau potently inhibited hippocampal long-term potentiation (LTP) at CA3-to-CA1 synapses. In contrast, tau monomers and fibrils appeared inactive. Neither baseline synaptic transmission, paired-pulse facilitation nor burst response during high-frequency conditioning stimulation was affected by the soluble tau aggregates. Similarly, certain AD brain soluble extracts inhibited LTP in a tau-dependent manner that was abrogated by either immunodepletion with, or coinjection of, a mid-region anti-tau monoclonal antibody (mAb), Tau5. Importantly, this tau-mediated block of LTP was prevented by administration of mAbs selective for the prion protein (PrP). Specifically, mAbs to both the mid-region (6D11) and $\mathrm{N}$-terminus (MI-0131) of PrP prevented inhibition of LTP by both recombinant and brain-derived tau. These findings indicate that $\operatorname{PrP}$ is a mediator of tau-induced synaptic dysfunction.

Key words: Alzheimer's disease; glutamate; microtubule-associated protein tau; prion protein; synaptic plasticity

Significance Statement

Here we report that certain soluble forms of tau selectively disrupt synaptic plasticity in the live rat hippocampus. Further, we show that monoclonal antibodies to cellular prion protein abrogate the impairment of long-term potentiation caused both by recombinant and Alzheimer's disease brain-derived soluble tau. These findings support a critical role for cellular prion protein in the deleterious synaptic actions of extracellular soluble tau in tauopathies, including Alzheimer's disease. Thus, approaches targeting cellular prion protein, or downstream pathways, might provide an effective strategy for developing therapeutics.

\section{Introduction}

The brains of Alzheimer's disease (AD) patients are characterized by tau-containing intracellular neurofibrillary tangles (NFTs)

Received July 5, 2018; revised Sept. 20, 2018; accepted Sept. 21, 2018.

Author contributions: T.O., I.K., M.S.P., A.B., D.M.W., and M.J.R. designed research; T.O., I.K., G.T.C., and G.F. performed research; W.H., A.J.M., M.G., and J.H. contributed unpublished reagents/analytic tools; T.O., I.K., and G.T.C. analyzed data; T.O., G.T.C., D.M.W., and M.J.R. wrote the paper.

This work was supported by AstraZeneca (to M.J.R. and D.M.W.), Science Foundation Ireland (14/IA/2571 to M.J.R.), Irish Health Research Board (HRA-POR-2015-1102 to M.J.R.), National Institutes of Health (R21 AG047505 to D.M.W.). We thank Vanya Petseva and Kenneth Dawson for their help with peptide characterization.

G.F., M.G., J.H., M.S.P. and A.B. are employees and shareholders of AstraZeneca. The remaining authors declare no competing financial interests.

Correspondence should be addressed to Michael J. Rowan, Pharmacology and Therapeutics, Watts Building, Trinity College Dublin, Dublin 2, Ireland. E-mail:mrowan@tcd.ie. and amyloid $\beta$-protein $(\mathrm{A} \beta)$-laden extracellular neuritic plaques. Tau is abnormally phosphorylated and aggregated in NFTs (Querfurth and LaFerla, 2010; Medeiros et al., 2011; Morris et al., 2011), and the presence of NFTs is associated with microtubule destabilization and compromised axonal transport (Querfurth and LaFerla, 2010; Scheltens et al., 2016). Indeed, tau pathology and glutamatergic synaptic loss correlate with the severity of dementia in AD (Terry et al., 1991; Terry, 2000; Nelson et al., 2009, 2012). 
Recent evidence implicates soluble, diffusible tau oligomers as important drivers of synaptotoxicity (Medina and Avila, 2014; Fá et al., 2016). Although tau is an intracellular protein, many forms of tau are present in CSF and in medium of cultured neurons (Pooler et al., 2013; Medina and Avila, 2014; Yamada et al., 2014; Bright et al., 2015; Kanmert et al., 2015; Chen et al., 2018; Guix et al., 2018; Hu et al., 2018; Sato et al., 2018). Significantly, exogenous application of soluble tau aggregates ( $\mathrm{S} \tau \mathrm{As})$ and tau oligomers prepared from AD brain can impair hippocampal synaptic plasticity in vitro (Lasagna-Reeves et al., 2011; Guerrero-Muñoz et al., 2015; Fá et al., 2016; Piacentini et al., 2017; Puzzo et al., 2017) and disrupt limbic system-dependent learning in mice (Lasagna-Reeves et al., 2012; Fá et al., 2016).

Extracellular, misfolded, tau is also implicated in the insidious propagation of tau pathology between brain regions, putatively starting in the entorhinal cortex and spreading through the hippocampus to other cortical areas (Braak and Del Tredici, 2011). Indeed, tau has been reported to be transferred between cells, at least partly via synapses (Liu et al., 2012; Soto, 2012; de Calignon et al., 2012; Hyman, 2014; Iba et al., 2015; Fu et al., 2016).

Similar mechanisms have been proposed for the spread of pathology in other neurodegenerative diseases (Jucker and Walker, 2011; Guo and Lee, 2014; Walsh and Selkoe, 2016; Aulić et al., 2017; Urrea et al., 2018). Preventing the binding of infectious prions to cell membrane-anchored $\mathrm{PrP}$ is currently under investigation as a means to treat transmissible spongiform encephalopathies (Klyubin et al., 2014b). Intriguingly, the binding of $\mathrm{A} \beta$ or $\alpha$-synuclein oligomers to cellular prion protein $\left(\mathrm{PrP}^{\mathrm{C}}\right)$ disrupts synaptic plasticity and impairs learning (Barry et al., 2011; Freir et al., 2011; Hu et al., 2014; Klyubin et al., 2014b; Ferreira et al., 2017; Zhang et al., 2017) and it has been suggested that $\operatorname{PrP}^{\mathrm{C}}$ may act as a molecular sensor for a broad range of oligomeric protein ligands (Resenberger et al., 2011; Béland and Roucou, 2012). Intriguingly, like A $\beta$ oligomers (Chen et al., 2010; Freir et al., 2011; Fluharty et al., 2013), full-length recombinant tau has been reported to bind to recombinant PrP in vitro (Wang et al., 2008) raising the prospect that at least some of tau's deleterious synaptic effects are mediated via cellular $\operatorname{PrP}^{\mathrm{C}}$.

Here, we compared the synaptic plasticity disrupting ability of AD brain-soluble tau and full-length recombinant tau441, which provides the greatest coverage of the different tau isoforms found in the brain (Sato et al., 2018). We report that the potent inhibition of long-term potentiation (LTP) in vivo by exogenously applied recombinant $\mathrm{S} \tau \mathrm{As}$ can be prevented by immunotargeting the primary $\mathrm{A} \beta$-binding region on $\mathrm{PrP}^{\mathrm{C}}$ (residues $\sim 95-110$ ). Moreover, certain soluble extracts of AD brain inhibited LTP in an $\mathrm{A} \beta$-independent manner and this inhibition was prevented by the mid-region tau monoclonal antibody (mAb) Tau5 and an anti-PrP mAb directed to residues in the secondary $\mathrm{A} \beta$ binding site (23-33).

\section{Materials and Methods}

Expression and aggregation of recombinant P301S tau. P301S_103histag_avi-tag full-length tau441 was overexpressed in BL21(DE3) bacterial cells that were lysed using BugBuster (Millipore). The clarified lysate was applied to a $5 \mathrm{ml}$ HisTrapHP column (GE Healthcare) in $2 \times$ PBS. Tau was eluted using a $0-500 \mathrm{~mm}$ imidazole gradient. Peak fractions were pooled and further purified using a Superdex 200 16/60 gel filtration column (GE Healthcare) eluted in PBS. Pooled fractions were then concentrated to $\sim 8 \mathrm{mg} / \mathrm{ml}$ using a spin concentrator with $30,000 \mathrm{Da}$ MWCO (Millipore).

P301S tau ( $1 \mathrm{ml}, 8 \mathrm{mg} / \mathrm{ml}$ ) was aggregated by incubation with $4 \mathrm{mg} / \mathrm{ml}$ heparin (Sigma-Aldrich) in PBS plus $30 \mathrm{~mm} 3-(N$-morpholino)propanesulfonic acid, $\mathrm{pH} 7.2$, at $37^{\circ} \mathrm{C}$ for $72 \mathrm{~h}$. Aggregated material was diluted in
$9 \mathrm{ml}$ PBS plus 1\% (v/v) Sarkosyl (Sigma-Aldrich) and left rocking for $1 \mathrm{~h}$ at room temperature. Insoluble tau was pelleted by ultracentrifugation for $1 \mathrm{~h}$ at $4^{\circ} \mathrm{C}$. The pellet was resuspended in $1 \mathrm{ml}$ PBS by vigorous pipetting and used as the fibril stock or sonicated at $100 \mathrm{~W}$ for $3 \times 20$ s using an ultrasonicator (Hielscher UP200St) to produce S $\tau$ As.

Expression and aggregation of wild-type tau (hTau40). Escherichia coli BL21 (DE3) were transformed with the $\mathrm{pNG} 2 / \mathrm{hTau} 40$ expression vector encoding full-length human tau441, and tau expressed and purified as described previously (Barghorn et al., 2005; O'Dowd et al., 2013). Protein purity and identity were assessed by SDS-PAGE/Coomassie Blue staining and mass spectrometry. Approximately $1.5 \mathrm{ml}$ of $50 \mu \mathrm{M}$ of tau monomer was concentrated to $1 \mathrm{ml}$ using $3000 \mathrm{Da}$ MWCO Amicon centrifugal filters (Millipore) and buffer exchanged into $50 \mathrm{~mm}$ 4-morpholineethanesulfonic acid (MES) sodium salt, $\mathrm{pH} 6.5$ using $5 \mathrm{ml} 7000$ MWCO Zeba desalting columns (ThermoFisher Scientific). To reduce cysteinemediated tau dimerization DTT (1,4-dithiothreitol) was added to achieve a final concentration of $100 \mathrm{~mm}$ and the mixture was heated at $55^{\circ} \mathrm{C}$ for $10 \mathrm{~min}$. Heparin was then added to yield an aggregation mixture containing $50 \mu \mathrm{M}$ tau, $100 \mu \mathrm{M}$ DTT and $50 \mu \mathrm{m}$ heparin. This solution was then agitated at $600 \mathrm{rpm}$ for $6 \mathrm{~d}$ at $37^{\circ} \mathrm{C}$ and fibrils harvested by centrifugation at $100,000 \times g$ for $1 \mathrm{~h}$ at $4^{\circ} \mathrm{C}$. Then $90 \%$ of the supernatant was removed and the fibril pellet washed by: (1) resuspension in sterile PBS, and (2) centrifugation at $100,000 \times g$ for $1 \mathrm{~h}$ at $4^{\circ} \mathrm{C}$. This wash step was repeated twice and the final pellet resuspended in sterile PBS and either used as a fibril stock or sonicated at $10 \mathrm{kHz}$ for $105 \mathrm{~s}$ bursts. Thereafter, the preparation was centrifuged at $16,000 \times g$ and $4^{\circ} \mathrm{C}$ for $10 \mathrm{~min}$, and $90 \%$ of the supernatant was collected, aliquoted, and stored frozen at $-80^{\circ} \mathrm{C}$ until used.

WT and P301S tau quantification. To quantify the monomeric tau equivalent present in aggregated P301S and wild-type (WT) preparations, $10 \mu \mathrm{l}$ of each stock was diluted with $10 \mu \mathrm{l}$ of $5 \mathrm{M}$ guanidinium hydrochloride (final concentration of $2.5 \mathrm{M}$ ) and allowed to disperse overnight at $4^{\circ} \mathrm{C}$. The following day, absorbance at $280 \mathrm{~nm}$ was measured and the concentration of tau monomer determined using the predicted extinction coefficient $\varepsilon_{280}=7450 \mathrm{M}^{-1} \mathrm{~cm}^{-1}$. Standards and samples were measured in triplicate.

Negative contrast electron microscopy. All solutions were prepared fresh and passed through a $0.2 \mu \mathrm{m}$ syringe filter (Millipore) immediately before use. Ten microliters of each sample was loaded onto Formvar carbon-coated copper grids (Electron Microscopy Sciences) and left to adhere for $1 \mathrm{~min}$. Proteins were then fixed by the addition of $10 \mu \mathrm{l} 0.5 \%$ glutaraldehyde for $1 \mathrm{~min}$. Excess solution was wicked dry using qualitative filter paper (VWR) and the grids washed with $10 \mu \mathrm{l}$ of MilliQ water $\times 2$. Samples were then stained with $2 \%$ uranyl acetate for $2 \mathrm{~min}$. Excess solution was wicked away with blotting paper and the grid was covered and left to dry for $5 \mathrm{~min}$. Proteins were visualized using a Joel 1200EX microscope.

End-point Thioflavin-T binding assay. Preparations of monomer, S $\tau$ As and end-stage fibrils ( $10 \mu \mathrm{l}$ of $20 \mu \mathrm{M}$ solutions) were added to half-area, nonbinding, black wall 96-well plates (3881, CorningLife Sciences) followed by $10 \mu \mathrm{l}$ of sterile filtered $200 \mu \mathrm{M}$ Thioflavin-T (ThT). Plates were sealed, protected from light and agitated at $300 \mathrm{rpm}$ for $45 \mathrm{~min}$ before fluorescence $\left(\mathrm{Ex}_{440}\right.$ and $\left.\mathrm{Em}_{480}\right)$ was read in a CLARIOstar plate reader (BMG Labtech) with gain set to 2000. In each case, samples were measured in triplicate.

Dynamic light scattering. Dynamic light scattering (DLS) was performed using a Zetasizer NanoZS spectrometer (Malvern Instrument) with a digital time correlator and a He-Ne laser (output power $=35 \mathrm{~mW}$ at $\lambda=632.8 \mathrm{~nm}$ ). DLS on non-globular filaments does not provide accurate absolute particle size measurement but can be used for quantifying aggregation and the relative size of aggregates. A $10 \mu \mathrm{M}$ solution of each aggregated tau preparation was prepared using $50 \mathrm{~mm}$ PBS buffer, $\mathrm{pH}$ 7.6. The solution $(500 \mu \mathrm{l})$ was then transferred to a quartz cell (3.3 mm internal diameter) maintained at $25^{\circ} \mathrm{C}$ and DLS intensity was measured.

Preparation of aqueous $A D$ brain extracts and immunodepletion. Human tissue was used in accordance with the Partner's Institutional Review Board (Protocol: Walsh BWH 2011). Frozen tissue was obtained from three end-stage $\mathrm{AD}$ cases (referred to as $\mathrm{AD} 1, \mathrm{AD} 2$, and $\mathrm{AD} 3$ ). 
Tissue from AD1 was obtained from the Massachusetts ADRC Neuropathology Core, Massachusetts General Hospital, and tissue from AD2 and AD3 was acquired from Tissue Solutions. AD1 was a 75-year-old woman, $\mathrm{AD} 2$ was a 79-year-old male, and AD3 was an 83-year-old woman. An aqueous extract was prepared from $\mathrm{AD} 1$ as described previously (Wang et al., 2017). Approximately $20 \mathrm{~g}$ of frontal cortex gray matter was dissected from AD1 brain and this material was then sliced into $\sim 2 \mathrm{~g}$ lots with a razor blade and homogenized in artificial CSF base buffer (aCSF-B; $124 \mathrm{~mm} \mathrm{NaCl}, 2.8 \mathrm{~mm} \mathrm{KCl}, 1.25 \mathrm{~mm} \mathrm{NaH} \mathrm{PO}_{4}, 26 \mathrm{~mm}$ $\mathrm{NaHCO}_{3}, \mathrm{pH}$ 7.4). The resulting $20 \%$ (w/v) homogenates were centrifuged at $200,000 \times g$ for $110 \mathrm{~min}$ and $4^{\circ} \mathrm{C}$ in a SW41 Ti rotor (Beckman Coulter). The upper $80 \%$ of the supernatant was removed and dialyzed against fresh aCSF-B using a Slide-A-Lyzer G2 Dialysis Cassettes, 2K MWCO (Fisher Scientific) at $4^{\circ} \mathrm{C}$ against a 100 -fold excess of aCSF-B with buffer changed three times over a $72 \mathrm{~h}$ period. Thereafter, the dialysate was divided into two parts. One portion was immunodepleted (ID) of $\mathrm{A} \beta$ by 3 rounds of $12 \mathrm{~h}$ incubations with the anti-A $\beta$ polyclonal antibody, AW7, plus Protein A Sepharose (PAS) beads at $4^{\circ} \mathrm{C}$. The second portion was treated in an identical manner, but incubated with pre-immune rabbit serum (PIS) plus PAS beads to yield a "mock ID" sample. Samples were cleared of beads and aliquots stored at $-80^{\circ} \mathrm{C}$ until used for biochemical or LTP experiments. Only $\sim 0.7 \mathrm{~g}$ of cortex was available from each of $\mathrm{AD} 2$ and $\mathrm{AD} 3$ and the volume of extracts (prepared using TBS in place of aCSF) was scaled appropriately. AD2 and $\mathrm{AD} 3$ extracts were clarified by centrifugation, dialyzed and subjected to ID or mock ID of $A \beta$ as described above.

$\mathrm{AD} 1$ brain extract, in $0.5 \mathrm{ml}$ aliquots, was depleted of tau by 2 rounds of $16 \mathrm{~h}$ incubations with the anti-tau mAb, Tau5 $(10 \mu \mathrm{g})$ and protein $\mathrm{G}$ agarose beads (PAG) beads (10 $\mu$ l; Roche). In parallel a portion of AD1 extract was mock ID using $10 \mu \mathrm{g}$ of the control mAb, 46-4 (Reeves et al., 1995), and PAG (10 $\mu \mathrm{l})$. The Tau5 and 46-4-treated samples were cleared of beads and then incubated with PAG alone to remove residual IgG. Aliquots stored at $-80^{\circ} \mathrm{C}$ until required.

Western blot analysis. To monitor immunodepletion of $\mathrm{A} \beta$ from aqueous brain extracts, immunoprecipitates (from $500 \mu \mathrm{l}$ homogenate) were analyzed as previously described (Hong et al., 2018). Briefly, proteins were eluted by boiling in $15 \mu \mathrm{l}$ of $2 \times$ sample buffer ( $50 \mathrm{~mm}$ Tris, $2 \% \mathrm{w} / \mathrm{v}$ SDS, $12 \% \mathrm{v} / \mathrm{v}$ glycerol with $0.01 \%$ phenol red) and separated on handpoured, 15 -well $16 \%$ polyacrylamide tris-tricine gels. Synthetic $A \beta_{1-42}$ $(10 \mathrm{ng}$ ) was run as a loading control and proteins were transferred to 0.2 $\mu \mathrm{m}$ nitrocellulose (Bio-Rad) at $400 \mathrm{~mA}$ and $4^{\circ} \mathrm{C}$ for $2 \mathrm{~h}$. Blots were microwaved in PBS, blocked and $\mathrm{A} \beta$ detected using the anti-A $\beta 40$ and anti-A $\beta 42$ antibodies $2 \mathrm{G} 3$ and $21 \mathrm{~F} 12$, respectively. After washing, blots were incubated with infrared-labeled secondary antibodies (Li-Cor) and developed with an Odyssey CLx imaging system (Li-Cor).

To monitor immunodepletion of tau from AD1 extracts, immunoprecipitates (from $500 \mu \mathrm{l}$ homogenate) were eluted by boiling in $20 \mu \mathrm{l} 2 \times$ lithium dodecyl sulfate (LDS) sample buffer $(53 \mathrm{~mm}$ Tris-HCl, $70 \mathrm{~mm}$ Trizma, 1\% LDS, 5\% glycerol, 0.255 mm EDTA, 0.02\% phenol red, $4 \%$ $\beta$-ME) and $5 \mu \mathrm{l} /$ well was resolved on 17 well, $4-12 \%$ NuPAGE Bis-Tris gels (ThermoFisher Scientific) electrophoresed in MES buffer (ThermoFisher Scientific). Five microliters of extracts with or without Tau5 immunodepletion were run in parallel, and synthetic hTau40 (1-441), K18 (244-372), K19 (244-372 minus repeat 2), eTau (2-230 minus inserts 1 and 2), and CT1 (231-441; $10 \mathrm{ng}$ ) were included as a loading control. Proteins were transferred to $0.2 \mu \mathrm{m}$ nitrocellulose (Bio-Rad) at $400 \mathrm{~mA}$ and $4^{\circ} \mathrm{C}$ for $2 \mathrm{~h}$ before blots were blocked and tau detected using the polyclonal antibody K9JA. After washing, blots were incubated with infrared-labeled secondary antibodies (Li-Cor) and developed with an Odyssey CLx imaging system (Li-Cor).

Tau ELISA. Tau in AD1 extract sample was measured using a midregion assay that uses BT2 for capture and Tau5 for detection (Kanmert et al., 2015; Hu et al., 2018). Briefly, BT2 was coated at $2.5 \mu \mathrm{g} / \mathrm{ml}$ in TBS for $1 \mathrm{~h}$ at $37^{\circ} \mathrm{C}$ and $300 \mathrm{rpm}$. Wells were then washed three times in TBS-Tween 20 (TBST; $100 \mu \mathrm{l}$ ) and then blocked in $100 \mu \mathrm{l}$ TBS containing $3 \% \mathrm{BSA}$ for $2 \mathrm{~h}$ at RT and $300 \mathrm{rpm}$. Wells were again washed three times with TBST $(100 \mu \mathrm{l})$ and $25 \mu \mathrm{l}$ samples, blanks or standards were applied and agitated for $16 \mathrm{~h}$ at $4^{\circ} \mathrm{C}$. The following day, alkaline phosphataseconjugated Tau 5 was added and incubated for $1 \mathrm{~h}$ at RT and $300 \mathrm{rpm}$.
Wells were then washed three times with TBST (100 $\mu \mathrm{l})$ and $50 \mu \mathrm{l}$ Tropix Sapphire II (Applied Biosystems) detection reagent was added and incubated for $30 \mathrm{~min}$ at RT and $300 \mathrm{rpm}$. All samples and standards were diluted in assay buffer and analyzed in triplicate. Standard curves were fitted to a five-parameter logistic function with $1 /$ Y 2 weighting using MasterPlex ReaderFit (MiraiBio). The lower limit of quantitation, which we define as the average +9 SE and $100 \pm 20 \%$ recovery for each standard, was $31.25 \mathrm{pg} / \mathrm{ml}$.

MSD A $\beta$ immunoassay. Monomeric A $\beta$ ending in Ala 42 was detected in aqueous brain extracts using an in-house Meso Scale Discovery (MSD) immunoassay using $\mathrm{m} 266(3 \mu \mathrm{g} / \mathrm{ml})$ as capture and biotinylated $21 \mathrm{~F} 12$ $(0.4 \mu \mathrm{g} / \mathrm{ml})$ for detection. Assays were performed using reagents from MSD and samples, standards and blanks were loaded in triplicate and analyzed as described previously (Mably et al., 2015; Hong et al., 2018).

Antibodies. MI-0131 antibody (human IgG1, binding epitope at residues 23-51 of PrP) was generated by AstraZeneca/MedImmune. Avastin (Bevacizumab, anti-VEGF, Genentech) was used as a human IgG1 isotype control. Tau5 (mouse IgG1, anti-tau 210-241), 6E10 (mouse IgG1, anti-A $\beta$ N-terminus), 6D11 (mouse IgG2a, anti-PrP 95-105) antibodies, and mouse IgG2a isotype control $\mathrm{mAb}$ were obtained from BioLegend. The $\mathrm{mAbs} \mathrm{m} 266,2 \mathrm{G} 3$ and $21 \mathrm{~F} 12$, which recognize $\mathrm{A} \beta 13-26, \mathrm{~A} \beta \mathrm{x}-40$ and $A \beta x-42$, respectively, were provided by Dr. Frederique Bard, Janssen (Johnson-Wood et al., 1997). K9JA (Dako) is a polyclonal antibody generated against tau 243-441 and AW7 is a polyclonal antibody to A $\beta$ produced in the Walsh laboratory (McDonald et al., 2012).

Animals, cannula implantation, and sample injection procedure. Adult (180-350 g, 7-11 weeks old) male Lister hooded rats were used in all experiments. The animals were housed under a $12 \mathrm{~h}$ light/dark cycle at room temperature $\left(19-22^{\circ} \mathrm{C}\right)$. Animal care and experimental protocols were performed in accordance with the approval of the Health Products Regulatory Authority, Ireland; using methods similar to those described previously (Klyubin et al., 2014a). To study the acute effect of recombinant tau and $\mathrm{AD}$ brain-derived extracts, rats were anesthetized with urethane (1.5-1.6 g/kg, i.p.), and a stainless-steel cannula (22 gauge, $0.7 \mathrm{~mm}$ outer diameter, length $13 \mathrm{~mm}$ ) was implanted above the right lateral ventricle ( $1 \mathrm{~mm}$ lateral to the midline and $4 \mathrm{~mm}$ below the surface of the dura). Intracerebroventricular injections were made via an internal cannula (28 gauge, $0.36 \mathrm{~mm}$ outer diameter). The solutions were injected via a Hamilton syringe at a maximum rate of $1 \mu \mathrm{l} / \mathrm{min}$. Verification of the placement of cannula was performed postmortem by checking the spread of ink dye after intracerebroventricular injection.

In vivo electrophysiology. Monopolar recording electrodes and twisted bipolar stimulating electrodes were constructed from Teflon-coated tungsten wires. Electrode implantation sites were identified using stereotaxic coordinates relative to bregma, with the recording site located 3.4 $\mathrm{mm}$ posterior to bregma and $2.5 \mathrm{~mm}$ lateral to midline, and stimulating site $4.2 \mathrm{~mm}$ posterior to bregma and $3.8 \mathrm{~mm}$ lateral to midline. The final placement of electrodes was optimized by using electrophysiological criteria and confirmed via postmortem analysis.

Field EPSPs were recorded from the stratum radiatum in the CA1 area of the right hippocampus in response to stimulation of the ipsilateral Schaffer collateral-commissural pathway. Test EPSPs were evoked at a frequency of $0.033 \mathrm{~Hz}$ and an intensity that triggered a 50\% maximum EPSP response. Paired-pulse facilitation (PPF) was tested using two stimuli at the test pulse intensity at a $40 \mathrm{~ms}$ interval. The magnitude of PPF was calculated as the ratio of amplitude of the second EPSP to the first.

LTP was induced using $200 \mathrm{~Hz}$ high-frequency stimulation (HFS) consisting of one set of 10 trains of 20 pulses (intertrain interval of $2 \mathrm{~s}$ ) at either the test pulse intensity or an intensity that evoked an EPSP amplitude that was $75 \%$ of the maximum. In one group of experiments we used a strong protocol consisting of three sets of 10 trains of 20 pulses, interset interval $5 \mathrm{~min}$, at an intensity evoking 75\% maximum EPSP.

The doses and volumes injected were chosen based on pilot experiments. Thus, for recombinant tau we performed dose-ranging experiments with the P301S preparations and used similar doses of WT tau. For the AD brain extracts, preliminary experiments with AD1 extract indicated that $5 \mu$ inhibited LTP partially $(n=3)$ whereas $10 \mu$ l exerted a strong inhibitory effect $(n=3)$. Similar experiments were performed for $\mathrm{AD} 2$ and $\mathrm{AD} 3$ extracts. In pilot studies the doses of antibodies injected 
did not affect control LTP (Tau5, $n=5$; Avastin, $n=2$ ). Similarly, 6D11 (Hu et al., 2018) and 6E10 (Klyubin et al., 2005) had no effect on control LTP.

Data analysis. Values presented are the mean \pm SEM percentage preinjection baseline EPSP amplitude over a 45 min period. For graphing purposes the EPSP data are grouped into 5 min epochs (average of 10 sweeps). For statistical analysis data are expressed as the average EPSP amplitude during the last $10 \mathrm{~min}$ epoch before and $170-180 \mathrm{~min}(3 \mathrm{~h})$ after HFS. The ability to induce LTP within each experimental group was assessed a priori using paired $t$ tests. Differences in the magnitude of potentiation between experimental groups were analyzed using repeated-measures two-way ANOVA with Dunnett's/Bonferroni/Tukey post hoc tests, as appropriate. A $p$ value of $<0.05$ was considered statistically significant. Statistical analyses were performed in Prism 6.0.

\section{Results}

\section{Soluble aggregates of recombinant tau protein impair LTP in vivo}

Because of its well known ability to aggregate into fibrils and its pathogenic role in familial dementia, initial studies used recombinant tau441 (2N4R) bearing the P301S mutation (Spillantini and Goedert, 2013; Sánchez et al., 2018). Subsequent studies used WT tau441 in view of its importance in AD and other tauopathies. Monomers, end-stage fibrils and $\mathrm{S} \tau \mathrm{As}$ were characterized by electron microscopy (EM) and tested for ThT binding. Monomeric WT and P301S tau contained no structures detectable by EM and did not bind ThT (Figs. 1B, 2B), whereas end-stage aggregates contained a mixture of straight and twisted filaments (Fig. $1 A, 2 A$ ) and produced robust ThT fluorescence (Figs. $1 B$, $2 B) . S \tau$ As also produced strong ThT binding and EM revealed a mixture of species, including imperfect spheres and abundant short fibrils of $\sim 4-10 \mathrm{~nm}$ diameter and $16-80 \mathrm{~nm}$ in length. Dynamic light scattering indicated that the predominant aggregates in P301S and WT S $\tau$ As had peak sizes of $\sim 50$ and $35 \mathrm{~nm}$, respectively (Figs. $1 C, 2 C$ ).

Subsequently, we investigated the effect of these three tau preparations on LTP in vivo by injecting them into the lateral cerebral ventricle of anesthetized rats. Field EPSPs were recorded (Fig. $1 D, E$, representative traces shown as insets) in the CA1 area before and after $200 \mathrm{~Hz}$ HFS of the Schaffer collateral/commissural pathway to assess the ability to induce LTP. In control animals, treated with vehicle (Veh), the application of HFS triggered robust and stable LTP, measuring $133.1 \pm 4.3 \%$ (mean \pm SEM) at $170-180 \mathrm{~min}$ post-HFS ( $p=0.004$ compared with pre-HFS baseline, paired $t$ test; $n=5)$. Comparing all six different groups using repeated measures two-way ANOVA (RM-2W-ANOVA; treatment: $F_{(5,24)}=15.62, p<0.0001$, interaction of treatment $\times$ time: $\left.F_{(5,24)}=7.59, p=0.0002\right)$ revealed that LTP was significantly inhibited in a dose-dependent manner by P301S S $\tau$ As (0.28 pmol: $127.2 \pm 4.6 \%, n=7 ; 1.4$ pmol: $102.4 \pm 5.3 \%, n=5$; 2.8 pmol: $90.66 \pm 3.8 \%, n=5 ; p=0.6729$ for 0.28 pmol and $p<$ 0.0001 for both 1.4 and $2.8 \mathrm{pmol}$ compared with Veh group, Dunnett's post hoc test; Fig. $1 E, F)$. Furthermore, the inhibitory effect of tau was dependent on protein aggregation status. In contrast to $S \tau$ As, injection of either P301S tau monomers (Mono: 16 pmol) or fibrils (Fibr: 23 pmol) 15 min before the HFS did not significantly affect LTP (Mono: $128.1 \pm 3.1 \%, n=4$; Fibr: $133.7 \pm 8.7 \%, n=4$; post hoc test, $p=0.8632$ and 0.9999 for Mono or Fibr, respectively, compared with Veh; Fig. 1D,F).

Importantly, doses of P301S S $\tau$ As that inhibited LTP did not affect baseline synaptic transmission, PPF or synaptic responses during HFS. Thus, injection of $S \tau$ As (1.4-2.8 pmol, i.c.v.) did not significantly affect mean EPSP amplitude over a $3 \mathrm{~h}$ postinjection period [S $\tau$ As: $95.5 \pm 2.1 \% 180-190 \mathrm{~min}$ postinjection, $p>$
0.6638 compared with $101 \pm 0.9 \%$ pre-injection, $n=6$ ( 3 at 1.4 and 2.8 pmol each), paired $t$ test; $p>0.05$ compared with $99.8 \pm$ $2 \%$ in the Veh group, $n=5, \mathrm{RM}-2 \mathrm{~W}$-ANOVA, treatment: $F_{(1,9)}=0.62, p=0.45$; interaction of treatment $\times$ time: $F_{(1,9)}=$ $2.9, p=0.12$; Fig. $1 I, J]$. Similarly, PPF (interstimulus interval 40 $\mathrm{ms}$ ), a measure of short-term synaptic plasticity, was not significantly changed over the $3 \mathrm{~h}$ postinjection period in these rats by the $\mathrm{S} \tau \mathrm{A}$ injection $(102 \pm 2.3 \%$ and $103 \pm 2 \%$ at $180-190 \mathrm{~min}$ postinjection in vehicle and $\mathrm{S} \tau \mathrm{A}$-injected group, respectively, $n=$ 5-6 per group; RM-2W-ANOVA, treatment: $F_{(1,9)}=0.85, p=$ 0.38 ; interaction of treatment $\times$ time: $F_{(1,9)}=0.42, p=0.53$; Fig. $1 K)$.

We also assessed whether the synaptic responses during the HFS ( 10 trains of 20 pulses at $200 \mathrm{~Hz}$ with an intertrain interval of $2 \mathrm{~s}$ ) were affected in the LTP experiments. As an index of synaptic responses we measured the integrated field potential area in bursts $2-10$ as a percentage of the area under curve of the first burst response. As can be seen in Figure $1 G$, the $\mathrm{S} \tau \mathrm{As}$ had no significant effect (RM-2W-ANOVA, treatment: $F_{(1,10)}=0.74$, $p=0.41$, interaction of treatment $\times$ time: $F_{(9,90)}=0.46, p=0.89$, $n=5$ per group).

These findings indicate that $\mathrm{S} \tau \mathrm{As}$ do not interfere with electrically evoked AMPA receptor-mediated transmission, shortterm plasticity or the synaptic burst responses.

Next, we tested the effect of S $\tau$ As on LTP induced by stronger HFS to determine whether we could overcome the block. The application of 3 sets of 10 trains of 20 pulses at $200 \mathrm{~Hz}$ in vehicle treated rats induced robust LTP (Veh: $130.9 \pm 3.7 \%, n=4, p=$ 0.0027 compared with baseline, paired $t$ ), whereas the same strong HFS failed to induce persistent LTP in rats injected with P301S S $\tau$ As (1.4 pmol; S $\tau$ As: $102.9 \pm 8 \%, n=4$; RM-2WANOVA, treatment: $F_{(1,6)}=6.356, p=0.0452$, interaction of treatment $\times$ time: $F_{(1,6)}=13.52, p=0.0104$, post hoc $p=0.0033$; Fig. $1 H)$.

We then determined whether human WT tau mimicked the disruption of synaptic plasticity by P301S tau by comparing the effects of monomers, S $\tau$ As and fibrils of WT tau. Whereas LTP was induced in animals injected with relatively high doses of WT tau monomers (25 pmol, $126.2 \pm 2.8 \%, n=4)$ and fibrils (20 pmol, $140.1 \pm 4.8 \%, n=4)$, it was significantly inhibited in animals receiving $1 \mathrm{pmol}$ of WT S $\tau$ As $(103.7 \pm 2 \%, n=5$; RM2W-ANOVA, treatment: $F_{(3,14)}=8.96, p<0.0001$, interaction of treatment $\times$ time: $F_{(3,14)}=5.43, p=0.0109 ; p=0.1627$, and 0.9954 for monomers and fibrils, respectively, $p<0.0001$ for WT S $\tau$ As, compared with $138 \pm 9.7 \%$ in Veh-treated rats, $n=5$, Dunnett test; Fig. $2 \mathrm{D}, \mathrm{E})$.

Together these experiments demonstrate that exogenous application of recombinant tau aggregates can impair synaptic plasticity, and in particular, highlight the importance of tau aggregation in mediating LTP impairment. Importantly, the LTP impairment was caused by brief exposure to very low doses of $\mathrm{S} \tau$ As indicating that extracellular soluble aggregates of tau have a rapid, potent disruptive effect on the mechanisms generating synaptic LTP in the rat hippocampus.

\section{LTP inhibition by certain soluble extracts of $\mathrm{AD}$ brain is tau-dependent}

To evaluate whether the deleterious effects of recombinant $S \tau$ As on LTP are mimicked by more pathophysiologically relevant AD tau species, we studied the role of tau in mediating the inhibition of LTP by human AD brain soluble extracts. Previously, we and others reported that soluble extracts of $\mathrm{AD}$ brain, that contain $\mathrm{A} \beta$ monomers and SDS-stable dimers, rapidly and potently inhibit 
A

\section{P301S tau}
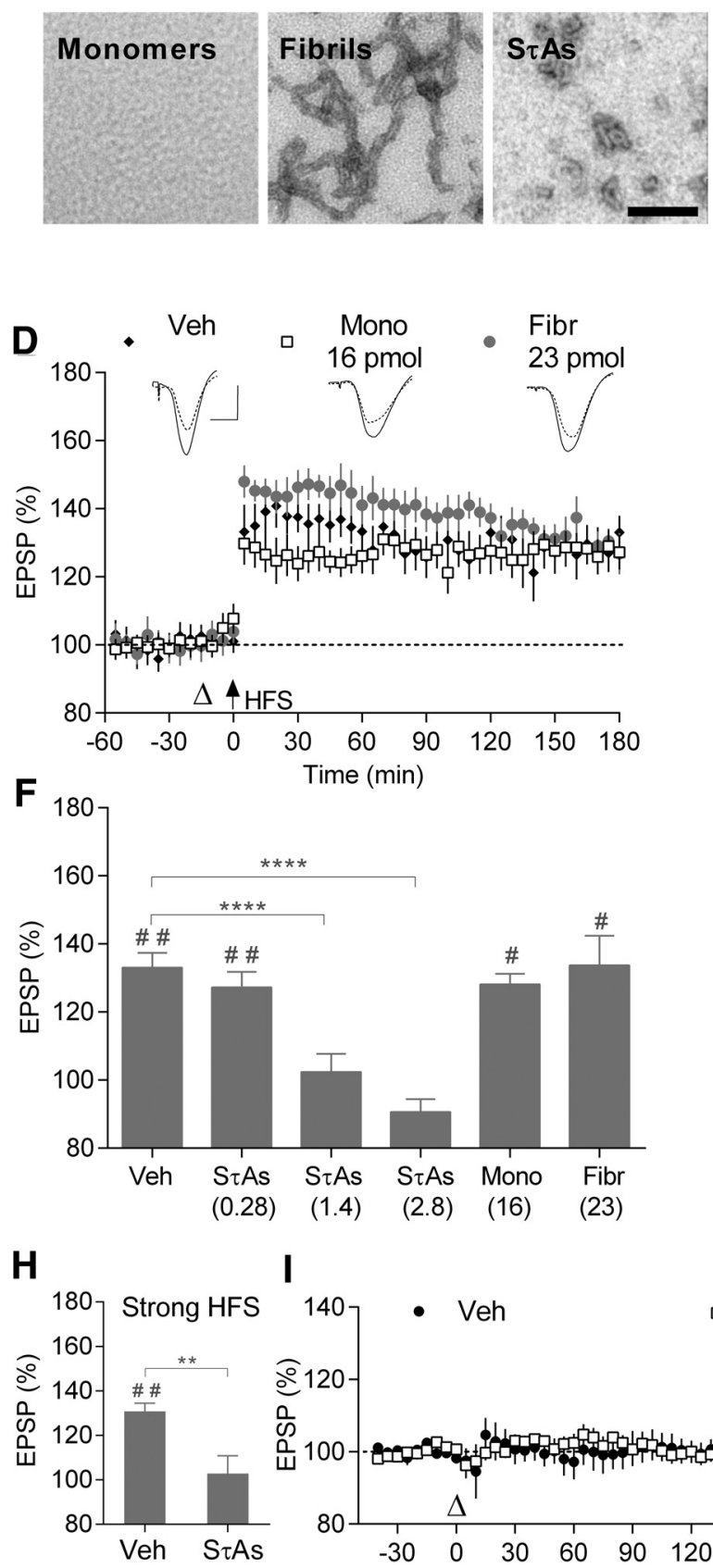

B

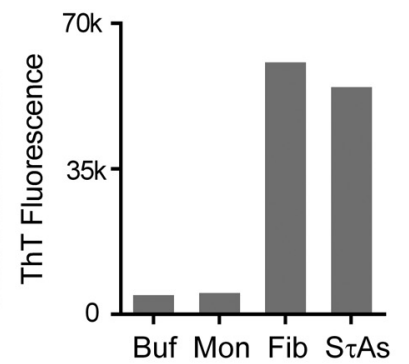

C

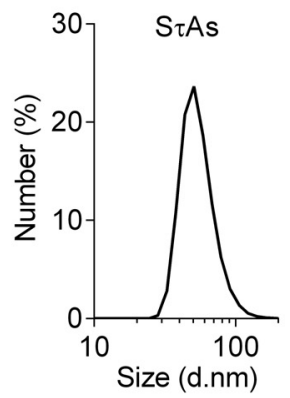

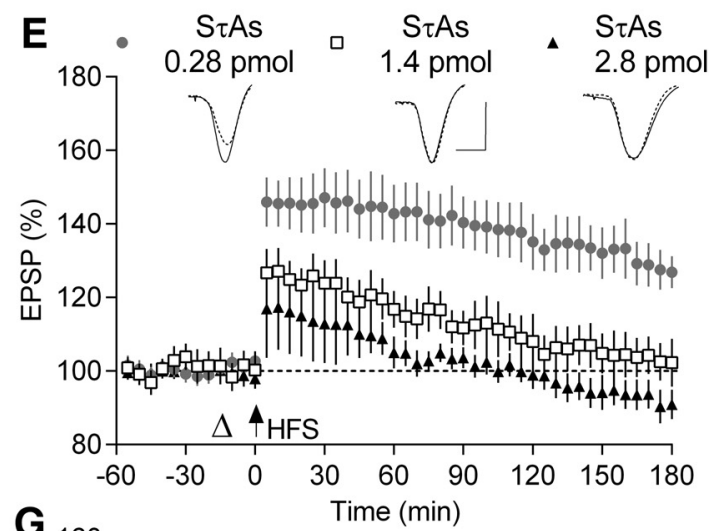
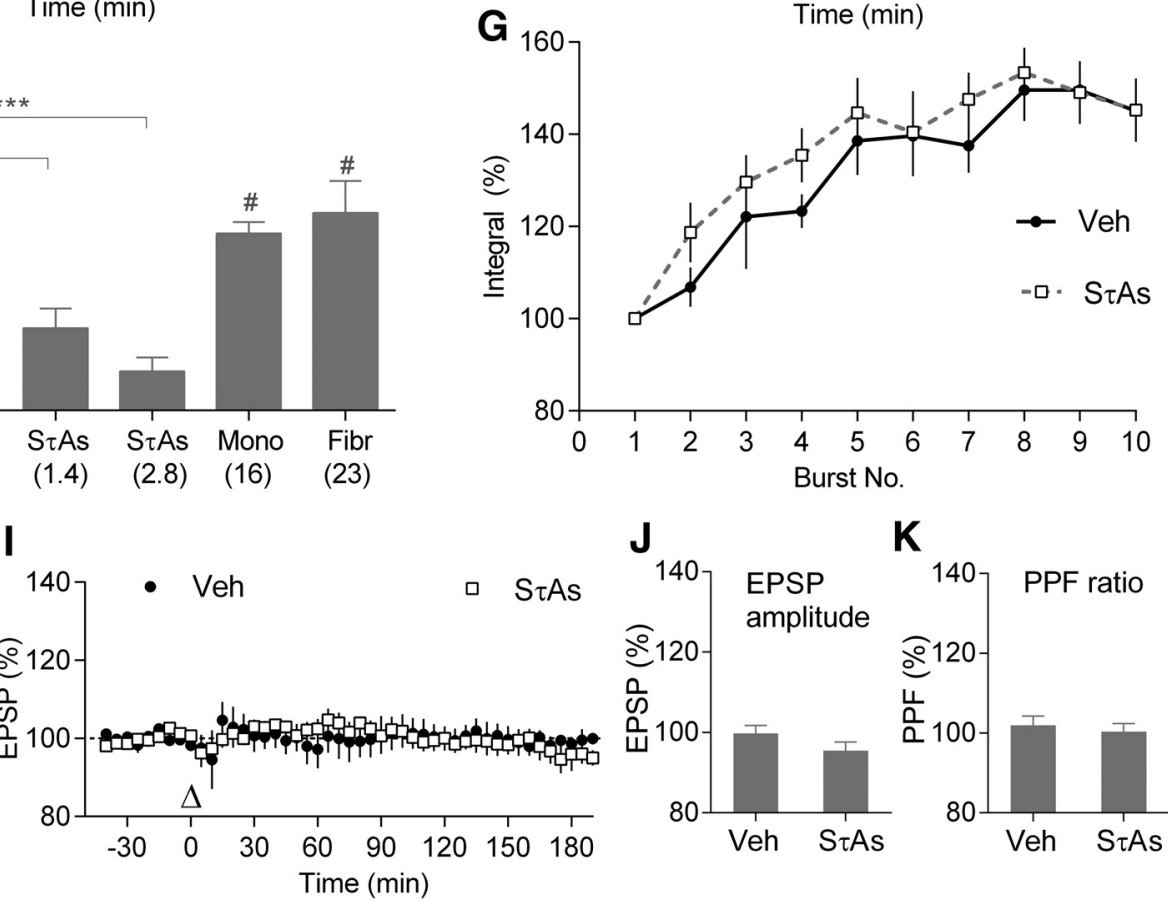

K

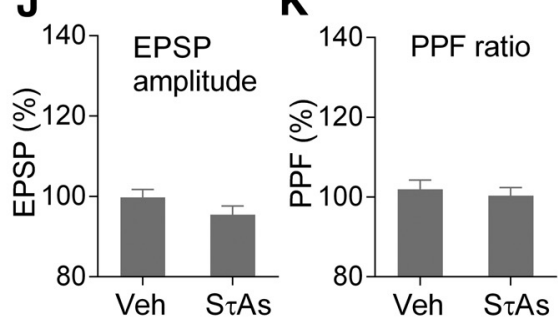

Figure 1. Soluble P301S tau aggregates, but not monomers or fibrils, potently inhibit LTP in vivo. $A$, Negative contrast electron micrographs of P301S tau monomers, fibrils and S $\tau$ As. Scale bar, $100 \mathrm{~nm}$. B, ThT binding of P301S tau monomers (Mon), fibrils (Fib), and S $\tau$ As (3 technical replicates in each group). C, Particle size distribution, peaking at $\sim 50 \mathrm{~nm}$, for $S \tau$ As using DLS (average of 3 technical replicates). D, E, Synaptic field EPSPs recorded in the CA1 area of anesthetized rats injected with (D) Veh (black diamonds; $n=5$ ), P301S tau monomers (16 pmol; open squares; $n=4)$, P301S tau fibrils ( 23 pmol; gray circles; $n=4$ ) or $(\boldsymbol{E})$ different doses of P301S S $\tau$ As: 0.28 pmol (gray circles; $n=7$ ), 1.4 pmol (open squares; $n=5$ ), or 2.8 pmol (black triangles; $n=5$ ). To induce LTP, HFS (arrow at time 0) was applied 15 min after intracerebroventricular injection (open triangle). Sample traces were recorded 10 min before (dotted line) and $3 \mathrm{~h}$ after HFS (solid line). $\boldsymbol{F}$, Summary bar charts showing the magnitude of LTP during the last $10 \mathrm{~min}$ for data in $\boldsymbol{D}$ and $\boldsymbol{E}$. Numbers in brackets represent dose (in pmol) of injected preparations. $\boldsymbol{G}$, Burst responses during the HFS (10 trains of 20 pulses at $200 \mathrm{~Hz}$ with a 2 s intertrain interval). Change in the burst response (compound EPSP integral) evoked by each train of stimuli, expressed as a percentage of the first burst response in animals pretreated with either Veh (black circles) or P301SS $\tau$ A (open squares; $n=5$ per group). $\boldsymbol{H}$, Summary bar charts showing the magnitude of $L T P$ induced by a stronger HFS protocol (sHFS; consisting of 3 sets of HFS at high intensity) in Veh and P301S $\tau$ As-treated groups ( $n=4$ for both groups). $\boldsymbol{I}-\boldsymbol{K}$, Baseline excitatory transmission was recorded for $>3 \mathrm{~h}$ after injection of Veh (black circles; $n=5$ ) or P301SS $\tau$ As (open squares; $n=6$ ). Summary bar charts of EPSP amplitude $(\boldsymbol{J})$ and PPF ( 40 ms interstimulus interval) ratios (EPSP2/EPSP1; $\boldsymbol{K}$ ) at $3 \mathrm{~h}$ postinjection. Values are mean \pm SEM. Scale bars: vertical, 2 mV; horizontal, 10 ms. ${ }^{\#} p<0.05,{ }^{\# \#} p<0.01$ compared with pre-HFS, paired $t$ test; ${ }^{* *} p<0.01$, ${ }^{* * *} p<0.0001$, two-way ANOVA with repeated-measures followed by Dunnett's multiple-comparison tests versus Veh group. 
A

\section{WT tau}
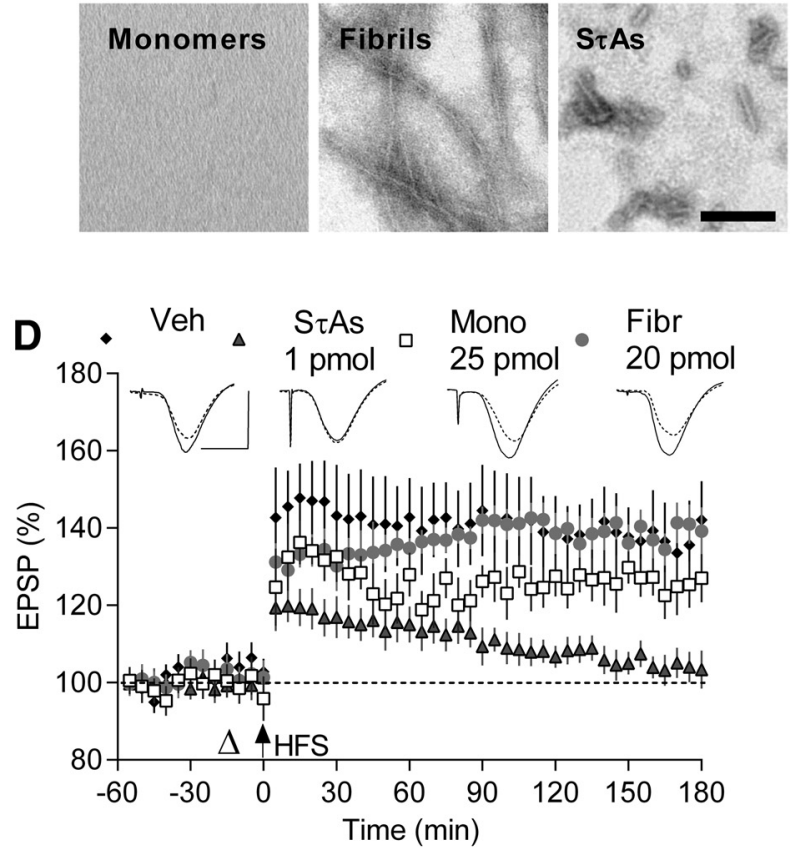

B

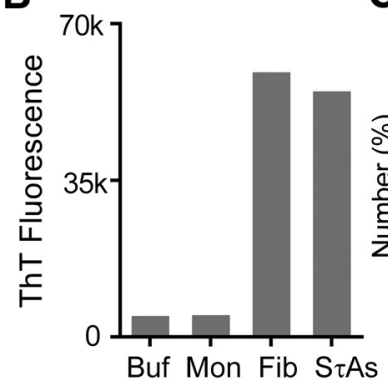

E

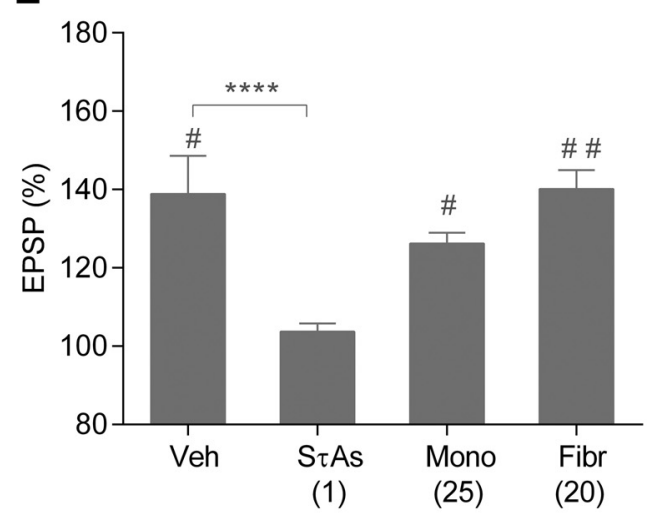

Figure 2. Soluble WT tau aggregates, but not monomers or fibrils, potently inhibit LTP. $\boldsymbol{A}$, Negative contrast electron micrographs of WT tau monomers, fibrils and $\mathrm{S} \tau \mathrm{As}$. Scale bar, $100 \mathrm{~nm}$. $\boldsymbol{B}$, ThT binding ( 3 technical replicates in each group). $\boldsymbol{C}$, Particle size distribution, peaking at $\sim 35 \mathrm{~nm}$, for $S \tau$ As using DLS (average of 3 technical replicates). $\boldsymbol{D}$, Time course graphs for the effects of vehicle (black diamonds; $n=5$ ), WT monomers ( 25 pmol; open squares; $n=4)$, WT fibrils ( 20 pmol; gray circles; $n=4)$, or WT S $\tau$ As ( 1 pmol; gray triangles; $n=5$ ) on the ability of HFS to induce LTP. $E$, Summary of the magnitude of potentiation at $3 \mathrm{~h}$ in groups shown in $\boldsymbol{D}$. ${ }^{\#} p<0.05,{ }^{\# \#} p<0.01$ (paired $t$ test); ${ }^{* * *} p<0.0001$ (RM-2W-ANOVA, Dunnett test).

LTP both in vitro (Shankar et al., 2008) and in vivo (Klyubin et al., 2014a), an effect that was prevented by selective ID of A $\beta$ from these extracts (Shankar et al., 2008; Barry et al., 2011; Freir et al., 2011; Jin et al., 2011; Borlikova et al., 2013; Hu et al., 2014; Klyubin et al., 2014b; Wang et al., 2017; Hong et al., 2018). However, recently we have found that $\sim 1$ in $15 \mathrm{AD}$ brain extracts retained their deleterious effects on LTP after depletion of A $\beta$.

Figure 3 shows that the water-soluble extract of an AD brain (7 $\mu$ l, i.c.v.), here referred to as $\mathrm{AD} 1$, that had been ID of $\mathrm{A} \beta$ using the polyclonal antibody AW7 still strongly inhibited LTP (AD1/ AW7: $93.4 \pm 7.2 \%, n=5$; compared with Veh: $142.4 \pm 7.4 \%$, $n=7$; RM-2W-ANOVA, treatment: $F_{(3,21)}=8.82, p=0.0006$, interaction of treatment $\times$ time: $F_{(3,21)}=9.55, p=0.0004 ; p<$ 0.0001 Tukey test; Fig. $3 B, G)$. AW7 effectively depleted AD1 brain of $\mathrm{A} \beta$, as evidenced by WB and ELISA (Fig. $3 A$ ). Compared with the mock ID extract treated with PIS, ID of AD1 extract with AW7 reduced the ELISA detected levels of $\mathrm{A} \beta \mathrm{x}-42$ by $\sim 80 \%$ (Fig. 3E).

Because tau can also inhibit LTP (Fá et al., 2016; Puzzo et al., 2017), we immunodepleted the AD1 brain extract using Tau5, a mid-region-directed anti-tau antibody, which recognizes a large number of tau species in AD brain (Nakano et al., 2004; Porzig et al., 2007). We confirmed the presence of tau in AD1 extract and subsequent immunoprecipitation of tau from that extract by WB (Fig. 3C). Notably, Tau5 ID decreased both WB and ELISA detected tau in the AD1 extract by $>80 \%$, compared with mock ID with the isotype control mAb 46-4 (Fig. $3 E, F$ ). Importantly, Tau5 ID abrogated the inhibitory effect of AD1 extract on LTP (AD1/Tau5: $134.1 \pm 8.7 \%, n=7$; compared with AD1/46-4: $107.5 \pm 3.5 \%, n=6 ; p=0.0042$ Tukey test; Fig. $3 D, G)$.

We also investigated two other extracts (AD2 and AD3) that inhibited LTP in an A $\beta$-independent manner. Because of insuf- ficient amount of these extracts, rather than ID with Tau5 we tested the LTP disruptive effect of these brain extracts when preincubated and coinjected with Tau5. In the case of AD2 extract statistical evaluation with RM-2W-ANOVA revealed a significant effect of treatment $\left(F_{(4,20)}=8.9, p=0.0003\right)$ and interaction of treatment $\times$ time $\left(F_{(4,20)}=8.88, p=0.0003\right.$; Fig. $\left.3 H\right)$. Acute injection with vehicle, $15 \mathrm{~min}$ before HFS, induced robust and stable LTP (Veh: $146 \pm 9.9 \%, n=6 ; p=0.0067$ compared with pre-HFS baseline, paired $t$ test). The injection of $A \beta$-containing AD2 brain soluble extract (10 $\mu$ l, i.c.v.) strongly inhibited LTP (AD2: $107.3 \pm 5.4 \%, n=5 ; p<0.0001$ compared with Veh, Tukey test; Fig. $3 H$ ). Again, in contrast to our previous experience with other soluble AD brain extracts (Barry et al., 2011; Hu et al., 2014; Klyubin et al., 2014b), ID of A $\beta$ from the AD2 brain sample with AW7 did not abrogate its ability to inhibit LTP (AD1/AW7: $103.3 \pm 2.2 \%, n=4 ; p<0.0001$ compared with Veh, Tukey test). This finding indicates that soluble $\mathrm{A} \beta$ was not responsible for the disruption of synaptic plasticity by soluble brain extract AD2. However, when $\mathrm{A} \beta$-ID AD2 brain extract ( 10 $\mu \mathrm{l})$ was co-administered with Tau $5(2.5 \mu \mathrm{g}$ in $5 \mu \mathrm{l})$ the subsequent application of HFS induced robust LTP (AD2/AW7+ Tau5: $144 \pm 9.6 \%, n=5$ ). In contrast, coinjection of the same extract with $6 \mathrm{E} 10(2.5 \mu \mathrm{g}$, i.c.v.), a monoclonal anti-A $\beta \mathrm{mAb}$, which acted as an IgG1 isotype control for Tau5, caused a marked reduction of potentiation compared with the AD2/AW7+Tau5 group (AD2/AW7 + 6E10: $91.6 \pm 9.3 \%, n=5, p<0.0001$, Tukey test; Fig. $3 H$ ). Together, these experiments suggest that soluble tau also mediates the impairment of synaptic plasticity by the AD2 brain extract.

Similar findings were obtained using a third AD brain soluble extract, AD3, that also inhibited LTP in an A $\beta$-independent manner. Overall RM-2W-ANOVA comparing four groups confirmed 


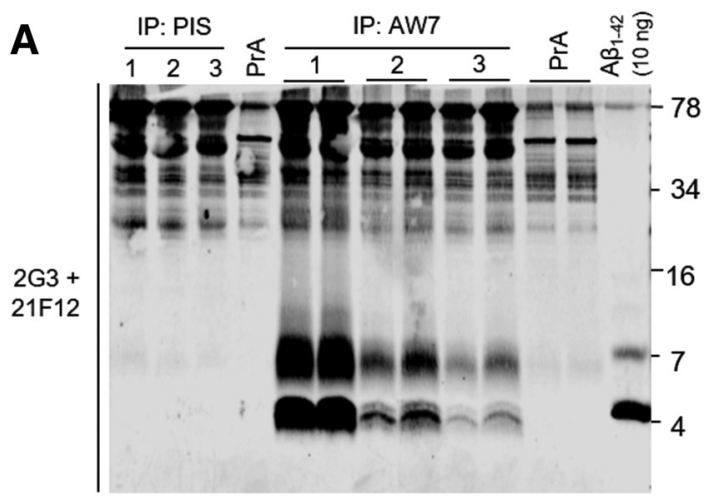

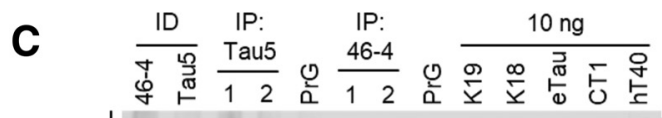
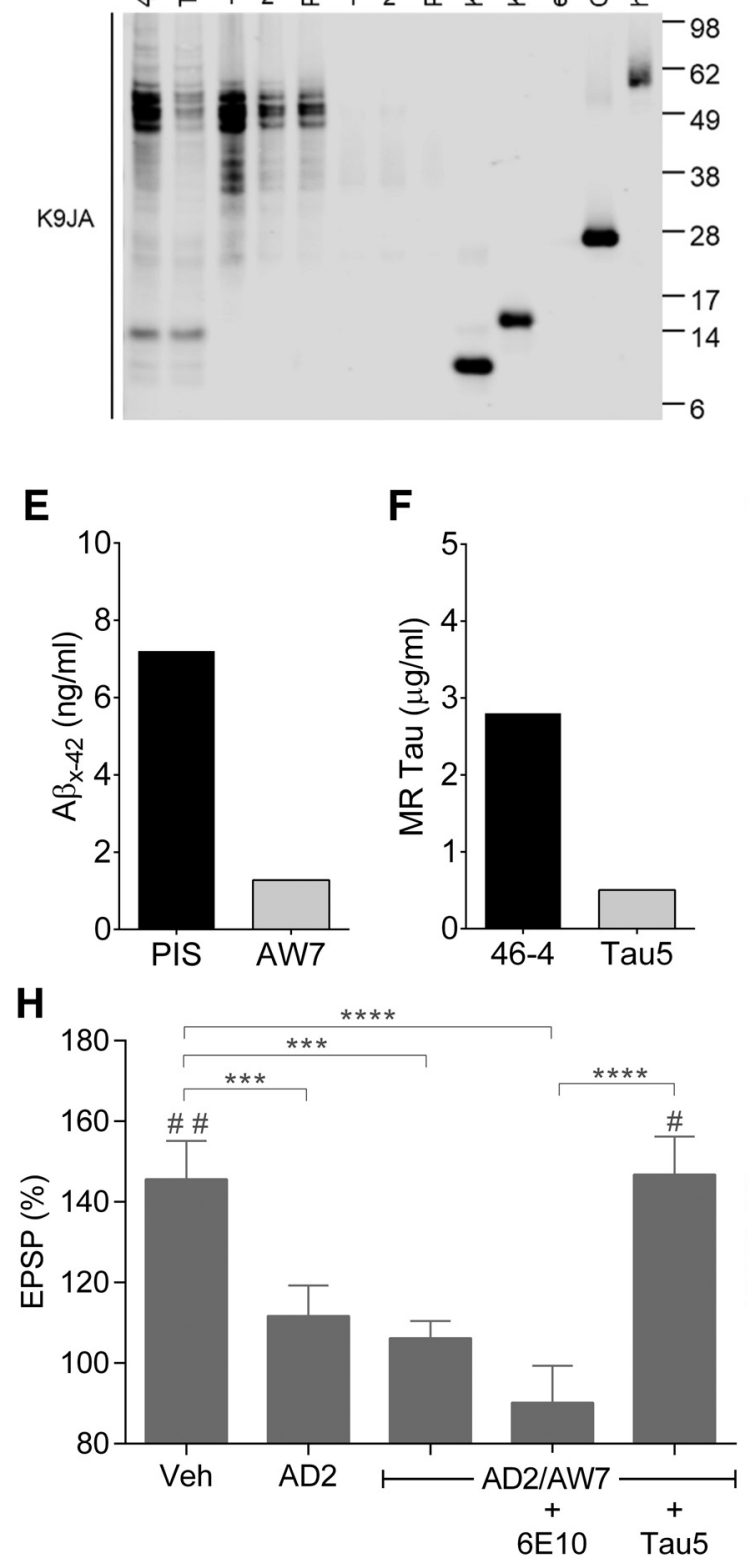

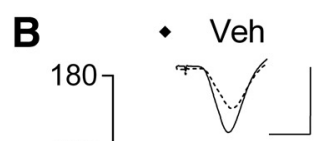

- AD1/AW7
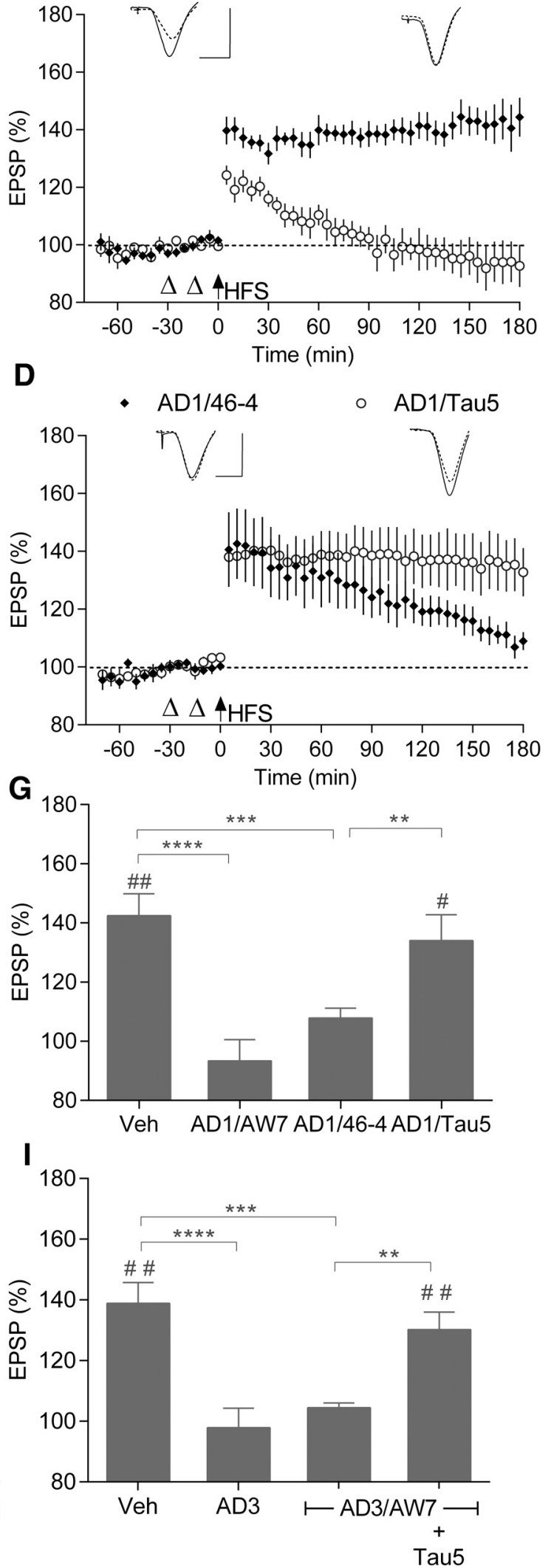

Figure 3. An anti-tau antibody, Tau5, abrogates the inhibition of LTP by soluble extracts of AD brain. $A$, Brain AD1 underwent three rounds (denoted 1-3) of immunoprecipitation (IP) of either AW7 or PIS. After the third AW7 IP the supernatant was incubated with protein A (PrA) alone. WB was performed using the anti-A $\beta_{40}$ and anti-A $\beta_{42}$ antibodies, 2 G3 and $21 F 12$. Ten nanograms of synthetic $A \beta_{1-42}$ were loaded as a control and the migration of molecular weight markers is shown on the right. $\boldsymbol{B}$, Time course of $L T P$ after intracerebroventricular injection of Veh (black diamonds; $n=7$ ), or AD1 brain extract immunodepleted of A $\beta$ by AW7 (AD1/AW7; open circles; $n=5$ ). C, AD1 extract was subjected to two rounds (denoted 1 and 2 ) of incubation with either Tau 5 or 46-4. After the second tau5 incubation, the supernatant was incubated with protein $\mathrm{G}$ (PrG) alone. WB was performed using the polyclonal, C-terminally directed, anti-tau (Figure legend continues.) 

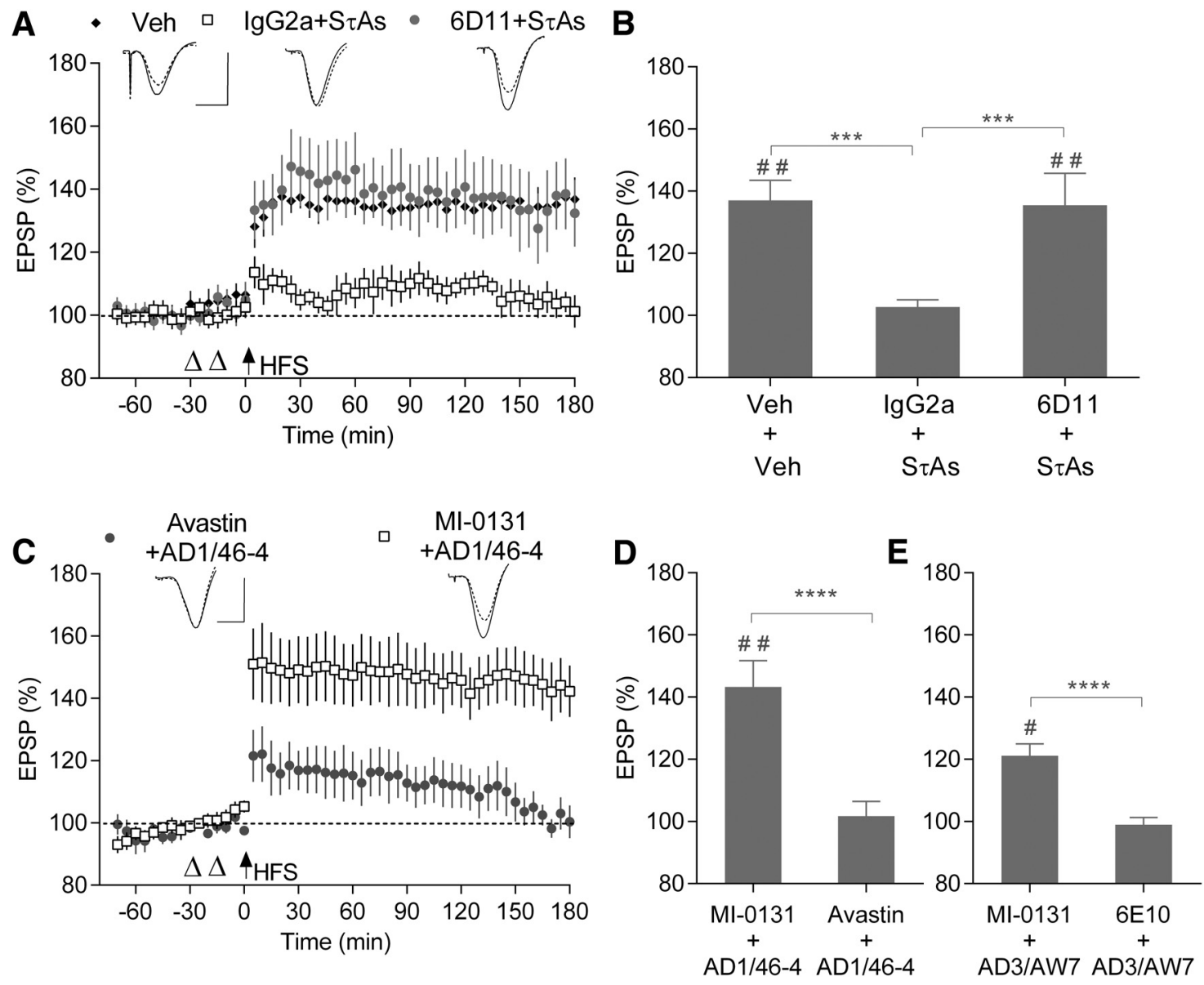

Figure 4. $\quad P r P C$ is required for tau-mediated inhibition of LTP. A, Effect of pre-injection of the anti-PrP mAb 6D11 intracerebroventricularly on the ability of $S \tau$ As to inhibit $L T P$. Animals received intracerebroventricular injections of vehicle twice (Veh + Veh; black diamonds; $n=5), 6 \mathrm{D} 11 \mathrm{mAb}(20 \mu \mathrm{g})$ before P301SS $\tau$ As (6D11 + S $\tau$ As; gray circles; $n=5)$ or lgG2a isotype control antibody $(20 \mu \mathrm{g})$ followed by P301S S $\tau$ As (IgG2a + S $\tau$ As; open squares; $n=5)$. $\boldsymbol{B}$, Values at $3 \mathrm{~h}$ post-HFS from $\boldsymbol{A}$. C, $\boldsymbol{D}$, Intracerebroventricular injection of the anti-PrP $\mathrm{mAb}$ MI-0131 before administration of AD1 extract prevented the inhibition of LTP. Animals were pretreated with $20 \mu \mathrm{g} \mathrm{MI-0131} \mathrm{(MI-0131} \mathrm{+} \mathrm{AD1/46-4;} \mathrm{open} \mathrm{squares;} n=5$ ) or the isotype control mAb Avastin (Avastin + AD1/46-4; gray circles; $n=5)$. $\boldsymbol{D}$, Values at $3 \mathrm{~h}$ from $\boldsymbol{C}$. E, Effect of pre-injection of the anti-PrP mAb MI- 0131 on the ability of the A $\beta$-ID soluble AD3 brain extract to inhibit LTP. Animals were pretreated with $20 \mu \mathrm{g} \mathrm{MI}-0131$ (MI-0131 + AD3/AW7; $n=5$ ) or the isotype control mAb 6E10 (6E10 + AD3/AW7; $n=5) .{ }^{\#} p<0.05,{ }^{\# \#} p<0.01$ (paired $t$ test); ${ }^{* * *} p<0.001^{* * * *} p<0.0001$ (RM-2W-AN0VA, Tukey or Bonferroni post hoc test as appropriate).

significant effect of treatment $\left(F_{(3,21)}=6.2, p=0.0035\right)$ and interaction of treatment $\times$ time $\left(F_{(3,21)}=7.15, p=0.0017\right.$; Fig. $3 I)$. Similar to extract $\mathrm{AD} 2$, injection of $\mathrm{AD} 3$ or AD3/AW7 $(10 \mu \mathrm{l}$, i.c.v.) before conditioning stimulation significantly impaired

(Figure legend continued.) antibody K9JA. Five microliters of homogenates post-ID with Tau5 and 46-4 were loaded on the left. Ten nanograms of synthetic K19, K18, eTau, CT1, and hTau40 (hT40) were loaded as control and molecular weight markers are shown on the right. D, Tau ID with Tau 5 abrogated the inhibition of LTP by AD1 extract (AD1/Tau5; open circles; $n=7$ ), unlike mock ID with 46-4 (AD1/46-4; black diamonds; $n=6)$. $E$, ID of AD1 with AW7 reduced $A \beta_{x-42}$ levels by $\sim 82 \%$ compared with mock ID with PIS. $F$, ID of AD1 with Tau 5 reduced mid-region (MR) tau by $\sim 82 \%$ compared with mock ID with $46-4$. G, Summary of LTP measured at $3 \mathrm{~h}$ in groups shown in $\boldsymbol{B}$ and $\boldsymbol{D}$. $\boldsymbol{H}$, An aqueous extract from a different AD brain (AD2) inhibited LTP in an $A \beta$-independent, but tau-dependent manner. Summary of LTP measured at $3 \mathrm{~h}$ in animals that received an intracerebroventricular injection of Veh $(n=6), A \beta$-containing human brain extract (AD2; $n=5$ ) or AD2 brain extract ID of A $\beta$ by AW7, (AD2/AW7; $n=4)$, AD2/AW7 brain extract together with $2.5 \mu \mathrm{g}$ of Tau5 mAb (AD2/AW7 + Tau5; $n=5$ ), and AD2/AW7 with isotype control mAb (AD2/AW7 + 6E10; $n=5)$. II, The role of tau in the $A \beta$-independent synaptic plasticity disrupting effect of another $A D$ brain extract (AD3) was also tested. Summary of $L T P$ measured at $3 \mathrm{~h}$ after injection of Veh $(n=7) ; A \beta$-containing brain extract, (AD3; $n=5) ; A \beta$-ID extract, (AD3/AW7; $n=5)$, or AD3/AW7 extract with $2.5 \mu \mathrm{g}$ Tau5 mAb (AD3/AW7 + Tau5; $n=8$ ). ${ }^{\#} p<0.05,{ }^{\# \#} p<$ 0.01 (paired $t$ test); ${ }^{* *} p<0.01,{ }^{* * *} p<0.001,{ }^{* * * *} p<0.0001$ (RM-2W-ANOVA, Tukey test). Scale bars: (in $\boldsymbol{B}, \boldsymbol{D})$; vertical, $2 \mathrm{mV}$; horizontal, $10 \mathrm{~ms}$.
LTP (AD3: $103.2 \pm 5 \%$, AD3/AW7: $106.9 \pm 1.83 \%, n=5$ for both groups, $p \leq 0.0001$ and 0.0002 for comparisons with Veh: $136.6 \pm 8 \%, n=7$, Tukey test; zfr;3 Fig. 3I). Importantly, the LTP impairment was tau-dependent because coinjection of Tau 5 $(2.5 \mu \mathrm{g})$ completely prevented the deficit (AD3/AW7+Tau5: $130.2 \pm 5.7 \%, n=7, p=0.5541$ compared with Veh and $p=$ 0.0036 compared with AD3/AW7 group, Tukey test; Fig. 3I).

\section{Cellular prion protein is required for tau-mediated inhibition of LTP}

Next we investigated whether or not the inhibition of LTP by soluble tau aggregates or $\mathrm{AD}$ brain-derived tau was mediated by $\operatorname{PrP}^{\mathrm{C}}$, a putative receptor for $\mathrm{A} \beta$ (Laurén et al., 2009) and certain tau species (Hu et al., 2018). A $\beta$ binding is believed to be mediated by two sites within the PrP, one located $\mathrm{N}$-terminal residues 23-33 (Chen et al., 2010; Younan et al., 2013) and the other around the central residues 87-112 (Laurén et al., 2009; Freir et al., 2011).

The murine mAb 6D11, which targets residues within the second $A \beta$ binding site, was previously shown to block $A \beta$ induced inhibition of LTP (Freir et al., 2011; Hu et al., 2018). Here we examined whether $\operatorname{PrP}^{\mathrm{C}}$ has a role in mediating the tau-induced inhibition of LTP in vivo. Pre-injecting 6D11 (20 $\mu \mathrm{g}$, 
i.c.v.), abrogated the LTP deficit caused by S $\tau$ As (Fig. 4A). Overall, we found a significant difference between groups (RM-2WANOVA, treatment: $F_{(2,12)}=4.83, p=0.0289$, interaction of treatment $\times$ time: $F_{(2,12)}=12, p=0.0014$; Fig. $\left.4 B\right)$. In control rats treated with two injections of vehicle, conditioning stimulation induced robust LTP (Veh, $137.1 \pm 6.4 \%, n=5, p=0.0041$, paired $t$ test). In contrast, in animals pretreated with an IgG2a isotype control antibody (20 $\mu$ g, i.c.v.), S $\tau$ As (P301S; 1.4 pmol, i.c.v.) significantly inhibited LTP (IgG2a + S $\tau$ As; $102.7 \pm 2.4 \%$ of baseline, $n=5 ; p=0.0005$ compared with Vehicle, Tukey test; Fig. 4B). Importantly, injection of the same dose of 6D11 $15 \mathrm{~min}$ before application of $\mathrm{S} \tau$ As prevented the impairment of LTP $(6 \mathrm{D} 11+$ S $\tau$ As, $135.5 \pm 10.2 \%, n=5 ; p=0.9768$ compared with Veh + Veh and $p=0.0008$ compared with IgG2a $+\mathrm{S} \tau \mathrm{As}$, Tukey test).

Finally, we examined the ability of the $\mathrm{N}$-terminally directed anti-PrP ${ }^{\mathrm{C}} \mathrm{mAb}, \mathrm{MI}-0131(20 \mu \mathrm{g}$, i.c.v.) to prevent the taudependent inhibition of LTP by two AD brain extracts (AD1 and $\mathrm{AD} 3$ ) that disrupted plasticity in an $\mathrm{A} \beta$-independent manner (Fig. 3G,I). In the case of AD1 extract, prior injection of MI-0131 prevented the inhibition of LTP (MI-0131+AD1/46-4: $143.3 \pm$ $8.5 \%, n=5)$ compared with the same dose of control IgG (Avastin +AD1/46-4: $101.7 \pm 4.7 \%, n=5$, RM-2W-ANOVA, treatment: $F_{(1,8)}=16.47, p=0.0036$, interaction of treatment $\times$ time: $F_{(1,8)}=19.28, p=0.0023 ; p<0.0001$, Bonferroni test; Fig. $4 C, D)$.

Similarly, pretreatment with MI-0131, but not the IgG1 isotype control antibody $(6 \mathrm{E} 10,20 \mu \mathrm{g})$ abrogated the inhibition of LTP by AD3 extract (MI-0131+AD3/AW7, $121.1 \pm 3.8 \%$; $6 \mathrm{E} 10+\mathrm{AD} 3 / \mathrm{AW} 7,98.2 \pm 2.3 \%, n=5$ for both groups; RM-2WANOVA, treatment: $F_{(1,8)}=28.12, p=0.0007$, interaction of treatment $\times$ time: $F_{(1,8)}=8.95, p=0.0173 ; P<0.0001$, Bonferroni test; Fig. $4 E$ ).

In summary, two antibodies to two different epitopes of $\operatorname{PrP}^{\mathrm{C}}$ abrogated the inhibition of LTP by two different sources of tau, recombinant soluble aggregated tau and $\mathrm{AD}$ brain-soluble extract. On the basis of the present findings, $\operatorname{PrP}^{\mathrm{C}}$ appears to be a crucial site of action for tau-mediated disruption of synaptic plasticity in vivo.

\section{Discussion}

We report here that certain soluble forms of tau selectively disrupt synaptic plasticity in the rat hippocampus in vivo. Both wildtype and P301S soluble aggregates of recombinant tau, but not monomers or fibrils, potently and selectively inhibited LTP. Similarly, certain AD brain soluble extracts inhibited LTP in a taudependent manner, being blocked by ID with, or coinjection of, an antibody to the mid-region of tau. Remarkably, antibodies to $\mathrm{PrP}^{\mathrm{C}}$ abrogated the LTP impairment caused both by the S $\tau$ As and the soluble tau-containing AD brain extracts. These findings support a critical role for $\operatorname{PrP}^{\mathrm{C}}$ in the deleterious synaptic actions of extracellular soluble tau in tauopathies, including AD.

As outlined in the Introduction, recent research has shifted emphasis from insoluble fibrillar forms of tau found in NFTs to more soluble tau aggregates in causing synaptic impairments in tauopathies (Lasagna-Reeves et al., 2011; Spires-Jones et al., 2011). The present data strongly support this view both for wildtype and mutant tau. Filaments formed by WT and the more aggregation-prone P301S tau appeared relatively inert when injected into the cerebral ventricle adjacent to the hippocampal site where LTP was assessed. Their lack of effectiveness is likely due to their large size, strongly limiting their ability to diffuse beyond the site of injection. In contrast to fibrillar tau, a similar injection of either WT or P301 S $\tau$ As very rapidly inhibited LTP of synaptic transmission with comparable high potency. That the aggregates were disruptive so quickly after application indicates that they are highly mobile, similar to synaptotoxic soluble aggregates of $\mathrm{A} \beta$ (Kasza et al., 2017) and is consistent with in vitro studies showing that bath application of soluble WT tau oligomers rapidly inhibit LTP in mouse hippocampal slices (Fá et al., 2016). In the present study the tau aggregates prepared by sonication appeared to be relatively large assemblies whereas tau oligomers prepared from cross-seeding (Lasagna-Reeves et al., 2010) or by peptide bond formation (Fá et al., 2016) were reported to be smaller. It is not known whether the shared ability to disrupt synaptic plasticity by the different preparations is mediated by the same soluble tau species. Interestingly, S $\tau$ As can propagate pathology more effectively than mature fibrils, presumably at least partly because of their more diffusible nature (Guo and Lee, 2014). Similar to Fá et al. (2016) who reported that monomers of 1N4R tau did not disrupt LTP in vitro, monomers of either WT or P301S full-length (2N4R) tau did not affect synaptic plasticity in vivo using doses $\sim 15-25$ times higher than the effective doses of $S \tau$ As, despite the likelihood that tau monomers are the most diffusible species of the three forms that we injected. Thus, the present data support the view that the synaptotoxicity of tau is highly aggregation dependent, with soluble aggregates being very disruptive and monomer relatively inert.

The deleterious effects of $S \tau$ As were selective for LTP. Doses of S $\tau$ As that powerfully inhibited LTP did not significantly affect baseline transmission or PPF, a short-term plasticity of that transmission. Moreover, there was no obvious change in the burst responses during the HFS. These findings support and extend a previous report that tau oligomers did not affect baseline transmission at concentrations that inhibited LTP in hippocampal slices (Fá et al., 2016). However, impaired astrocytic release of gliotransmitters, including ATP, has been found to mediate tau oligomer-induced rapid reduction in glutamate release by cultured hippocampal neurons, as evidenced by a decrease in the frequency of miniature EPSCs and depolarization-evoked synaptic vesicle release (Piacentini et al., 2017). The lack of significant change in baseline synaptic transmission and PPF in the present studies is likely because the concentration of tau achieved in vivo was $<100 \mathrm{nM}$, which was required to reduce transmitter release in vitro. Indeed, given that the injectate will be substantially diluted in the CSF and brain interstitial fluid, only sub-nanomolar concentrations are likely to be achieved after intracerebroventricular injection of the threshold dose of $\sim 1$ pmol S $\tau$ As.

Similar to full-length tau oligomers, AD brain-derived tau oligomers potently inhibit LTP (Lasagna-Reeves et al., 2012; Fá et al., 2016; Hu et al., 2018). Here, we tested the ability of soluble extracts of $\mathrm{AD}$ brain prepared by homogenization but, unlike prior investigators, we did not modify the extracts chemically to enrich oligomers. Although most soluble AD brain extracts inhibit LTP in an A $\beta$-dependent manner, a small number of extracts block LTP in an $A \beta$-independent manner and we found that ID with, or coinjection of, the anti-tau mAb, Tau5, prevented this effect. Aqueous brain extracts are expected to contain a rich array of tau forms and species derived from both intracellular and extracellular sources (Min et al., 2010; Sato et al., 2018). Although tau antibodies can act via numerous mechanisms and it is possible that Tau5 might also bind endogenous rat tau, given the findings with Tau5 ID and the rapidity of the protection against the inhibition of LTP by the AD brain soluble extract, a direct neutralization of species of tau that include the mid-region of tau in the extract is the most likely explanation for the efficacy of coinjected Tau5. The efficacy of Tau5 makes it unlikely that 
truncated forms of tau lacking the Tau5 binding epitope (amino acids 210-241 of full-length tau), are the active soluble form of tau in the AD extract. Indeed, it is likely that a form of Tau5recognized tau also mediates the inhibition of LTP by soluble tau in the secretomes of induced pluripotent stem cell-derived neurons (Hu et al., 2018).

The finding that only a small minority of soluble extracts of $\mathrm{AD}$ brain appear to contain significant amounts of synaptotoxic tau, whereas the vast majority contain synaptotoxic $\mathrm{A} \beta$, raises the more general issue of the relative contribution of $\mathrm{A} \beta$ and tau oligomers to $\mathrm{AD}$ pathogenesis, a subject of a large and diverse literature (Roberson et al., 2007; Zempel et al., 2013; Manassero et al., 2016; Vargas-Caballero et al., 2017; Ittner and Ittner, 2018). It is difficult to explain why the relative levels of these two synaptotoxic proteins appear to dichotomize between brain extracts. In particular, why significant levels of synaptotoxic tau appear not to be present in all $\mathrm{AD}$ soluble brain extracts is unclear. Because removal of $\mathrm{A} \beta$ by ID did not prevent the inhibition of LTP it seems unlikely that synaptotoxic tau needs to be complexed with $\mathrm{A} \beta$. However, the formation of complexes between different forms of soluble tau and $\mathrm{A} \beta$ may influence the relative concentration of synaptotoxic species present in a given $\mathrm{AD}$ soluble brain extract (Guo et al., 2006; Wallin et al., 2018). Such an interaction could explain the divergence of responsible synaptotoxic proteins in different soluble AD brain extracts. Such a mechanism is consistent with our previous finding that soluble synaptotoxic tau and $A \beta$ species in certain samples of secretomes of different genetic forms of $\mathrm{AD}$ appeared to be mutually exclusive (Hu et al., 2018).

On the basis of the present findings that LTP inhibition caused by soluble recombinant tau and soluble tau-containing AD brain extract was prevented by anti-PrP antibodies, $\mathrm{PrP}^{\mathrm{C}}$ appears to be essential for tau-mediated disruption of synaptic plasticity in vivo. In previous studies we reported that $\mathrm{A} \beta$-containing soluble extract of AD brain inhibited LTP in an $\mathrm{A} \beta$ - and PrP-dependent manner both in vivo (Barry et al., 2011) and in vitro (Freir et al., 2011) using antibodies to the central $\mathrm{A} \beta$-binding region (residues $~ 95-110$ ) and helix 1 of $\operatorname{PrP}^{\mathrm{C}}$, and $\operatorname{PrP}^{\mathrm{C}}$-null mice. In the present study an antibody directed to the $\mathrm{N}$-terminal $\mathrm{A} \beta$-binding region on $\operatorname{PrP}^{\mathrm{C}}$ (residues $\sim 23-31$ ) prevented tau-dependent $\mathrm{AD}$ brain inhibition of LTP, raising the prospect that cellular $\operatorname{PrP}^{\mathrm{C}}$ might act as a cell-surface receptor/acceptor for both soluble A $\beta$ (Purro et al., 2018) and tau (Wang et al., 2008; Hu et al., 2018) in $\mathrm{AD}$ brain. In addition, the recent report of a selective $\mathrm{PrP} / \alpha$ synuclein oligomer interaction (Ferreira et al., 2017) points to a common requirement for $\operatorname{PrP}^{\mathrm{C}}$ in the mediation of the synaptic plasticity disrupting and neurotoxic actions of a variety of aggregating proteins (Resenberger et al., 2011). Thus, an emerging body of evidence supports the hypothesis that $\operatorname{PrP}^{\mathrm{C}}$ may be a major site responsible for synaptic dysfunction and pathology induced by soluble protein aggregates derived from diseaserelevant human $\mathrm{AD}$ brains.

$\operatorname{PrP}^{\mathrm{C}}$ is an extracellular protein tethered to the membrane by glycosylphophatidylinositol. Nevertheless, the present findings do not rule out an intracellular site mediating the synaptic plasticity disrupting action of soluble tau. $\operatorname{PrP}^{\mathrm{C}}$ can act as a coreceptor to aberrantly promote signaling by transmembrane proteins, including metabotropic glutamate receptor 5 (Um et al., 2013). Furthermore, extracellular tau oligomers can be rapidly taken up into cells via mechanisms that require APP (Piacentini et al., 2017; Puzzo et al., 2017), which, like $\operatorname{PrP}^{\mathrm{C}}$, also is required for $\mathrm{A} \beta$ synaptotoxicity (Puzzo et al., 2017; Wang et al., 2017). Future studies examining these and other pathways will be necessary to determine how exogenous application of certain forms of tau robustly inhibited LTP, even when induced by strong HFS.

Although tau is predominantly an intracellular protein, there is growing evidence that it is released into the extracellular fluid under physiological as well as pathological conditions (Yamada et al., 2011; Chai et al., 2012; Karch et al., 2012; Bright et al., 2015; Kanmert et al., 2015; Guix et al., 2018). Newly synthesized tau is truncated and actively released by human neurons over several days and is cleared in an isoform-dependent manner from CSF, with tau isoforms that are more fibrillogenic potentially having faster kinetics (Kanmert et al., 2015; Sato et al., 2018). Great interest has been generated in the role of extracellular misfolded tau in the propagation of pathology trans-synaptically whereas much less is known regarding the role of extracellular tau in mediating synaptic dysfunction. It will be important to characterize the forms responsible for synaptotoxicity to inform ongoing clinical trials targeting extracellular tau with immunotherapy. The present findings clearly implicate tau isoforms that include the mid-region sequence recognized by Tau 5 in causing synaptic plasticity disruption.

Together with previous research showing that exogenously applied tau oligomers rapidly impair learning in mice (Fá et al., 2016; Puzzo et al., 2017) the present in vivo findings support the proposal that certain soluble tau forms may contribute to early tauopathy symptoms independent of NFT formation or significant neurodegeneration. Moreover, the discovery of the critical role of $\operatorname{PrP}^{\mathrm{C}}$ in mediating synaptotoxic actions of tau as well as $\mathrm{A} \beta$ supports a strategy targeting such a common target.

\section{References}

Aulić S, Masperone L, Narkiewicz J, Isopi E, Bistaffa E, Ambrosetti E, Pastore B, De Cecco E, Scaini D, Zago P, Moda F, Tagliavini F, Legname G (2017) alpha-synuclein amyloids hijack prion protein to gain cell entry, facilitate cell-to-cell spreading and block prion replication. Sci Rep 7:10050. CrossRef Medline

Barghorn S, Biernat J, Mandelkow E (2005) Purification of recombinant tau protein and preparation of Alzheimer-paired helical filaments in vitro. Methods Mol Biol 299:35-51. Medline

Barry AE, Klyubin I, Mc Donald JM, Mably AJ, Farrell MA, Scott M, Walsh DM, Rowan MJ (2011) Alzheimer's disease brain-derived amyloidbeta-mediated inhibition of LTP in vivo is prevented by immunotargeting cellular prion protein. J Neurosci 31:7259-7263. CrossRef Medline

Béland M, Roucou X (2012) The prion protein unstructured N-terminal region is a broad-spectrum molecular sensor with diverse and contrasting potential functions. J Neurochem 120:853-868. Medline

Borlikova GG, Trejo M, Mably AJ, Mc Donald JM, Sala Frigerio C, Regan CM, Murphy KJ, Masliah E, Walsh DM (2013) Alzheimer brain-derived amyloid beta-protein impairs synaptic remodeling and memory consolidation. Neurobiol Aging 34:1315-1327. CrossRef Medline

Braak H, Del Tredici K (2011) Alzheimer's pathogenesis: is there neuronto-neuron propagation? Acta Neuropathol 121:589-595. CrossRef Medline

Bright J, Hussain S, Dang V, Wright S, Cooper B, Byun T, Ramos C, Singh A, Parry G, Stagliano N, Griswold-Prenner I (2015) Human secreted tau increases amyloid-beta production. Neurobiol Aging 36:693-709. CrossRef Medline

Chai X, Dage JL, Citron M (2012) Constitutive secretion of tau protein by an unconventional mechanism. Neurobiol Dis 48:356-366. CrossRef Medline

Chen S, Yadav SP, Surewicz WK (2010) Interaction between human prion protein and amyloid-beta $(\mathrm{A} \beta)$ oligomers: role OF $\mathrm{N}$-terminal residues. J Biol Chem 285:26377-26383. CrossRef Medline

Chen Z, Mengel D, Keshavan A, Rissman R, Billinton A, Perkinton M, Percival-Alwyn J, Schultz A, Properzi M, Johnson K, Selkoe D, Sperling L, Patel P, Zetterberg H, Galasko D, Schott J, Walsh D (2018) Learnings about the complexity of extracellular tau aid development of a bloodbased screen for Alzheimer's disease. Alzheimers Dement pii: S15525260(18)33561-1. CrossRef Medline 
de Calignon A, Polydoro M, Suárez-Calvet M, William C, Adamowicz DH, Kopeikina KJ, Pitstick R, Sahara N, Ashe KH, Carlson GA, Spires-Jones TL, Hyman BT (2012) Propagation of tau pathology in a model of early Alzheimer's disease. Neuron 73:685-697. CrossRef Medline

Fá M, Puzzo D, Piacentini R, Staniszewski A, Zhang H, Baltrons MA, Li Puma DD, Chatterjee I, Li J, Saeed F, Berman HL, Ripoli C, Gulisano W, Gonzalez J, Tian H, Costa JA, Lopez P, Davidowitz E, Yu WH, Haroutunian V, et al. (2016) Extracellular tau oligomers produce an immediate impairment of LTP and memory. Sci Rep 6:19393. CrossRef Medline

Ferreira DG, Temido-Ferreira M, Miranda HV, Batalha VL, Coelho JE, Szegö ÉM, Marques-Morgado I, Vaz SH, Rhee JS, Schmitz M, Zerr I, Lopes LV, Outeiro TF (2017) $\alpha$-Synuclein interacts with $\operatorname{PrP}(\mathrm{C})$ to induce cognitive impairment through mGluR5 and NMDAR2B. Nat Neurosci 20: 1569-1579. CrossRef Medline

Fluharty BR, Biasini E, Stravalaci M, Sclip A, Diomede L, Balducci C, La Vitola P, Messa M, Colombo L, Forloni G, Borsello T, Gobbi M, Harris DA (2013) An N-terminal fragment of the prion protein binds to amyloidbeta oligomers and inhibits their neurotoxicity in vivo. J Biol Chem 288: 7857-7866. CrossRef Medline

Freir DB, Nicoll AJ, Klyubin I, Panico S, Mc Donald JM, Risse E, Asante EA, Farrow MA, Sessions RB, Saibil HR, Clarke AR, Rowan MJ, Walsh DM, Collinge J (2011) Interaction between prion protein and toxic amyloid beta assemblies can be therapeutically targeted at multiple sites. Nat Commun 2:336. CrossRef Medline

Fu H, Hussaini SA, Wegmann S, Profaci C, Daniels JD, Herman M, Emrani S, Figueroa HY, Hyman BT, Davies P, Duff KE (2016) 3D visualization of the temporal and spatial spread of tau pathology reveals extensive sites of tau accumulation associated with neuronal loss and recognition memory deficit in aged tau transgenic mice. PLoS One 11:e0159463. CrossRef Medline

Guerrero-Muñoz MJ, Gerson J, Castillo-Carranza DL (2015) Tau oligomers: the toxic player at synapses in Alzheimer's disease. Front Cell Neurosci 9:464. Medline

Guix FX, Corbett GT, Cha DJ, Mustapic M, Liu W, Mengel D, Chen Z, Aikawa E, Young-Pearse T, Kapogiannis D, Selkoe DJ, Walsh DM (2018) Detection of aggregation-competent tau in neuron-derived extracellular vesicles. Int J Mol Sci 19:E663. CrossRef Medline

Guo JL, Lee VM (2014) Cell-to-cell transmission of pathogenic proteins in neurodegenerative diseases. Nat Med 20:130-138. CrossRef Medline

Guo JP, Arai T, Miklossy J, McGeer PL (2006) A $\beta$ and tau form soluble complexes that may promote self aggregation of both into the insoluble forms observed in Alzheimer's disease. Proc Natl Acad Sci U S A 103: 1953-1958. CrossRef Medline

Hong W, Wang Z, Liu W, O'Malley TT, Jin M, Willem M, Haass C, Frosch MP, Walsh DM (2018) Diffusible, highly bioactive oligomers represent a critical minority of soluble $\mathrm{A} \beta$ in Alzheimer's disease brain. Acta Neuropathol 136:19-40. CrossRef Medline

Hu NW, Nicoll AJ, Zhang D, Mably AJ, O’Malley T, Purro SA, Terry C, Collinge J, Walsh DM, Rowan MJ (2014) mGlu5 receptors and cellular prion protein mediate amyloid-beta-facilitated synaptic long-term depression in vivo. Nat Commun 5:3374. CrossRef Medline

Hu NW, Corbett GT, Moore S, Klyubin I, O’Malley TT, Walsh DM, Livesey FJ, Rowan MJ (2018) Extracellular forms of a $\beta$ and tau from iPSC models of Alzheimer's disease disrupt synaptic plasticity. Cell Rep 23:19321938. CrossRef Medline

Hyman BT (2014) Tau propagation, different tau phenotypes, and prionlike properties of tau. Neuron 82:1189-1190. CrossRef Medline

Iba M, McBride JD, Guo JL, Zhang B, Trojanowski JQ, Lee VM (2015) Tau pathology spread in PS19 tau transgenic mice following locus coeruleus (LC) injections of synthetic tau fibrils is determined by the LC's afferent and efferent connections. Acta Neuropathol 130:349-362. CrossRef Medline

Ittner A, Ittner LM (2018) Dendritic tau in Alzheimer's disease. Neuron 99:13-27. CrossRef Medline

Jin M, Shepardson N, Yang T, Chen G, Walsh D, Selkoe DJ (2011) Soluble amyloid beta-protein dimers isolated from Alzheimer cortex directly induce tau hyperphosphorylation and neuritic degeneration. Proc Natl Acad Sci U S A 108:5819-5824. CrossRef Medline

Johnson-Wood K, Lee M, Motter R, Hu K, Gordon G, Barbour R, Khan K, Gordon M, Tan H, Games D, Lieberburg I, Schenk D, Seubert P, McConlogue L (1997) Amyloid precursor protein processing and A beta42 deposition in a transgenic mouse model of Alzheimer disease. Proc Natl Acad Sci U S A 94:1550-1555. CrossRef Medline

Jucker M, Walker LC (2011) Pathogenic protein seeding in Alzheimer disease and other neurodegenerative disorders. Ann Neurol 70:532-540. CrossRef Medline

Kanmert D, Cantlon A, Muratore CR, Jin M, O'Malley TT, Lee G, YoungPearse TL, Selkoe DJ, Walsh DM (2015) C-terminally truncated forms of tau, but not full-length tau or its C-terminal fragments, are released from neurons independently of cell death. J Neurosci 35:10851-10865. CrossRef Medline

Karch CM, Jeng AT, Goate AM (2012) Extracellular tau levels are influenced by variability in tau that is associated with tauopathies. J Biol Chem 287: 42751-42762. CrossRef Medline

Kasza Á, Penke B, Frank Z, Bozsó Z, Szegedi V, Hunya Á, Németh K, Kozma G, Fülöp L (2017) Studies for improving a rat model of Alzheimer's disease: icv administration of well characterized beta-amyloid 1-42 oligomers induce dysfunction in spatial memory. Molecules 22:E2007. CrossRef Medline

Klyubin I, Walsh DM, Lemere CA, Cullen WK, Shankar GM, Betts V, Spooner ET, Jiang L, Anwyl R, Selkoe DJ, Rowan MJ (2005) Amyloid beta protein immunotherapy neutralizes a $\beta$ oligomers that disrupt synaptic plasticity in vivo. Nat Med 11:556-561. CrossRef Medline

Klyubin I, Ondrejcak T, Hayes J, Cullen WK, Mably AJ, Walsh DM, Rowan MJ (2014a) Neurotransmitter receptor and time dependence of the synaptic plasticity disrupting actions of Alzheimer's disease $A \beta$ in vivo. Philos Trans R Soc Lond B Biol Sci 369:20130147. Medline

Klyubin I, Nicoll AJ, Khalili-Shirazi A, Farmer M, Canning S, Mably A, Linehan J, Brown A, Wakeling M, Brandner S, Walsh DM, Rowan MJ, Collinge J (2014b) Peripheral administration of a humanized anti-PrP antibody blocks Alzheimer's disease $\mathrm{A} \beta$ synaptotoxicity. J Neurosci 34: 6140-6145. CrossRef Medline

Lasagna-Reeves CA, Castillo-Carranza DL, Guerrero-Muoz MJ, Jackson GR, Kayed R (2010) Preparation and characterization of neurotoxic tau oligomers. Biochemistry 49:10039-10041. CrossRef Medline

Lasagna-Reeves CA, Castillo-Carranza DL, Jackson GR, Kayed R (2011) Tau oligomers as potential targets for immunotherapy for Alzheimer's disease and tauopathies. Curr Alzheimer Res 8:659-665. CrossRef Medline

Lasagna-Reeves CA, Castillo-Carranza DL, Sengupta U, Guerrero-Munoz MJ, Kiritoshi T, Neugebauer V, Jackson GR, Kayed R (2012) Alzheimer brain-derived tau oligomers propagate pathology from endogenous tau. Sci Rep 2:700. CrossRef Medline

Laurén J, Gimbel DA, Nygaard HB, Gilbert JW, Strittmatter SM (2009) Cellular prion protein mediates impairment of synaptic plasticity by amyloid-beta oligomers. Nature 457:1128-1132. CrossRef Medline

Liu L, Drouet V, Wu JW, Witter MP, Small SA, Clelland C, Duff K (2012) Trans-synaptic spread of tau pathology in vivo. PLoS One 7:e31302. CrossRef Medline

Mably AJ, Liu W, Mc Donald JM, Dodart JC, Bard F, Lemere CA, O’Nuallain B, Walsh DM (2015) Anti-a $\beta$ antibodies incapable of reducing cerebral $\mathrm{a} \beta$ oligomers fail to attenuate spatial reference memory deficits in J20 mice. Neurobiol Dis 82:372-384. CrossRef Medline

Manassero G, Guglielmotto M, Zamfir R, Borghi R, Colombo L, Salmona M, Perry G, Odetti P, Arancio O, Tamagno E, Tabaton M (2016) Betaamyloid 1-42 monomers, but not oligomers, produce PHF-like conformation of tau protein. Aging Cell 15:914-923. CrossRef Medline

McDonald JM, Cairns NJ, Taylor-Reinwald L, Holtzman D, Walsh DM (2012) The levels of water-soluble and Triton-soluble a $\beta$ are increased in Alzheimer's disease brain. Brain Res 1450:138-147. CrossRef Medline

Medeiros R, Baglietto-Vargas D, LaFerla FM (2011) The role of tau in Alzheimer's disease and related disorders. CNS Neurosci Ther 17:514-524. CrossRef Medline

Medina M, Avila J (2014) The role of extracellular tau in the spreading of neurofibrillary pathology. Front Cell Neurosci 8:113. CrossRef Medline

Min SW, Cho SH, Zhou Y, Schroeder S, Haroutunian V, Seeley WW, Huang EJ, Shen Y, Masliah E, Mukherjee C, Meyers D, Cole PA, Ott M, Gan L (2010) Acetylation of tau inhibits its degradation and contributes to tauopathy. Neuron 67:953-966. CrossRef Medline

Morris M, Maeda S, Vossel K, Mucke L (2011) The many faces of tau. Neuron 70:410-426. CrossRef Medline

Nakano H, Kobayashi K, Sugimori K, Shimazaki M, Miyazu K, Hayashi M, Furuta H (2004) Regional analysis of differently phosphorylated tau 
proteins in brains from patients with Alzheimer's disease. Dement Geriatr Cogn Disord 17:122-131. CrossRef Medline

Nelson PT, Braak H, Markesbery WR (2009) Neuropathology and cognitive impairment in Alzheimer disease: a complex but coherent relationship. J Neuropathol Exp Neurol 68:1-14. CrossRef Medline

Nelson PT, Alafuzoff I, Bigio EH, Bouras C, Braak H, Cairns NJ, Castellani RJ, Crain BJ, Davies P, Del Tredici K, Duyckaerts C, Frosch MP, Haroutunian V, Hof PR, Hulette CM, Hyman BT, Iwatsubo T, Jellinger KA, Jicha GA, Kövari E, et al. (2012) Correlation of Alzheimer disease neuropathologic changes with cognitive status: a review of the literature. J Neuropathol Exp Neurol 71:362-381. CrossRef Medline

O’Dowd ST, Ardah MT, Johansson P, Lomakin A, Benedek GB, Roberts KA, Cummins G, El Agnaf OM, Svensson J, Zetterberg H, Lynch T, Walsh DM (2013) The ELISA-measured increase in cerebrospinal fluid tau that discriminates Alzheimer's disease from other neurodegenerative disorders is not attributable to differential recognition of tau assembly forms. J Alzheimers Dis 33:923-928. CrossRef Medline

Piacentini R, Li Puma DD, Mainardi M, Lazzarino G, Tavazzi B, Arancio O, Grassi C (2017) Reduced gliotransmitter release from astrocytes mediates tau-induced synaptic dysfunction in cultured hippocampal neurons. Glia 65:1302-1316. CrossRef Medline

Pooler AM, Phillips EC, Lau DH, Noble W, Hanger DP (2013) Physiological release of endogenous tau is stimulated by neuronal activity. EMBO Rep 14:389-394. CrossRef Medline

Porzig R, Singer D, Hoffmann R (2007) Epitope mapping of mAbs AT8 and Tau5 directed against hyperphosphorylated regions of the human tau protein. Biochem Biophys Res Commun 358:644-649. CrossRef Medline

Purro SA, Nicoll AJ, Collinge J (2018) Prion protein as a toxic acceptor of amyloid-beta oligomers. Biol Psychiatry 83:358 -368. CrossRef Medline

Puzzo D, Piacentini R, Fá M, Gulisano W, Li Puma DD, Staniszewski A, Zhang H, Tropea MR, Cocco S, Palmeri A, Fraser P, D'Adamio L, Grassi C, Arancio O (2017) LTP and memory impairment caused by extracellular $\mathrm{A} \beta$ and tau oligomers is APP-dependent. eLife 6:e26991. CrossRef Medline

Querfurth HW, LaFerla FM (2010) Alzheimer's disease. N Engl J Med 362: 329-344. CrossRef Medline

Reeves JP, Lo CY, Klinman DM, Epstein SL (1995) Mouse monoclonal antibodies to human immunodeficiency virus glycoprotein 120 generated by repeated immunization with glycoprotein 120 from a single isolate, or by sequential immunization with glycoprotein 120 from three isolates. Hybridoma 14:235-242. CrossRef Medline

Resenberger UK, Harmeier A, Woerner AC, Goodman JL, Müller V, Krishnan R, Vabulas RM, Kretzschmar HA, Lindquist S, Hartl FU, Multhaup G, Winklhofer KF, Tatzelt J (2011) The cellular prion protein mediates neurotoxic signalling of beta-sheet-rich conformers independent of prion replication. EMBO J 30:2057-2070. CrossRef Medline

Roberson ED, Scearce-Levie K, Palop JJ, Yan F, Cheng IH, Wu T, Gerstein H, Yu GQ, Mucke L (2007) Reducing endogenous tau ameliorates amyloid beta-induced deficits in an Alzheimer's disease mouse model. Science 316:750-754. CrossRef Medline

Sánchez MP, García-Cabrero AM, Sánchez-Elexpuru G, Burgos DF, Serratosa JM (2018) Tau-induced pathology in epilepsy and dementia: notions from patients and animal models. Int J Mol Sci 19:E1092. CrossRef Medline

Sato C, Barthélemy NR, Mawuenyega KG, Patterson BW, Gordon BA, JockelBalsarotti J, Sullivan M, Crisp MJ, Kasten T, Kirmess KM, Kanaan NM, Yarasheski KE, Baker-Nigh A, Benzinger TLS, Miller TM, Karch CM, Bateman RJ (2018) Tau kinetics in neurons and the human central nervous system. Neuron 97:1284-1298.e7. CrossRef Medline

Scheltens P, Blennow K, Breteler MM, de Strooper B, Frisoni GB, Salloway S, Van der Flier WM (2016) Alzheimer's disease. Lancet 388:505-517. CrossRef Medline

Shankar GM, Li S, Mehta TH, Garcia-Munoz A, Shepardson NE, Smith I, Brett FM, Farrell MA, Rowan MJ, Lemere CA, Regan CM, Walsh DM, Sabatini BL, Selkoe DJ (2008) Amyloid-beta protein dimers isolated directly from Alzheimer's brains impair synaptic plasticity and memory. Nat Med 14:837-842. CrossRef Medline
Soto C (2012) In vivo spreading of tau pathology. Neuron 73:621-623. CrossRef Medline

Spillantini MG, Goedert M (2013) Tau pathology and neurodegeneration. Lancet Neurol 12:609-622. CrossRef Medline

Spires-Jones TL, Kopeikina KJ, Koffie RM, de Calignon A, Hyman BT (2011) Are tangles as toxic as they look? J Mol Neurosci 45:438-444. CrossRef Medline

Terry RD (2000) Cell death or synaptic loss in Alzheimer disease. J Neuropathol Exp Neurol 59:1118-1119. CrossRef Medline

Terry RD, Masliah E, Salmon DP, Butters N, DeTeresa R, Hill R, Hansen LA, Katzman R (1991) Physical basis of cognitive alterations in Alzheimer's disease: synapse loss is the major correlate of cognitive impairment. Ann Neurol 30:572-580. CrossRef Medline

Um JW, Kaufman AC, Kostylev M, Heiss JK, Stagi M, Takahashi H, Kerrisk ME, Vortmeyer A, Wisniewski T, Koleske AJ, Gunther EC, Nygaard HB, Strittmatter SM (2013) Metabotropic glutamate receptor 5 is a coreceptor for Alzheimer $\mathrm{A} \beta$ oligomer bound to cellular prion protein. Neuron 79:887-902. CrossRef Medline

Urrea L, Segura-Feliu M, Masuda-Suzukake M, Hervera A, Pedraz L, García Aznar JM, Vila M, Samitier J, Torrents E, Ferrer I, Gavín R, Hagesawa M, Del Río JA (2018) Involvement of cellular prion protein in alphasynuclein transport in neurons. Mol Neurobiol 55:1847-1860. CrossRef Medline

Vargas-Caballero M, Denk F, Wobst HJ, Arch E, Pegasiou CM, Oliver PL, Shipton OA, Paulsen O, Wade-Martins R (2017) Wild-type, but not mutant $\mathrm{N} 296 \mathrm{H}$, human tau restores $\mathrm{A} \beta$-mediated inhibition of LTP in tau $^{-1-}$ mice. Front Neurosci 11:201. CrossRef Medline

Wallin C, Hiruma Y, Wärmländer S, Huvent I, Jarvet J, Abrahams JP, Gräslund A, Lippens G, Luo J (2018) The neuronal tau protein blocks in vitro fibrillation of the amyloid- $\beta(\mathrm{A} \beta)$ peptide at the oligomeric stage. J Am Chem Soc 140:8138-8146. CrossRef Medline

Walsh DM, Selkoe DJ (2016) A critical appraisal of the pathogenic protein spread hypothesis of neurodegeneration. Nat Rev Neurosci 17:251-260. CrossRef Medline

Wang XF, Dong CF, Zhang J, Wan YZ, Li F, Huang YX, Han L, Shan B, Gao C, Han J, Dong XP (2008) Human tau protein forms complex with PrP and some GSS- and fCJD-related PrP mutants possess stronger binding activities with tau in vitro. Mol Cell Biochem 310:49-55. CrossRef Medline

Wang Z, Jackson RJ, Hong W, Taylor WM, Corbett GT, Moreno A, Liu W, Li S, Frosch MP, Slutsky I, Young-Pearse TL, Spires-Jones TL, Walsh DM (2017) Human brain-derived $A \beta$ oligomers bind to synapses and disrupt synaptic activity in a manner that requires APP. J Neurosci 37:1194711966. CrossRef Medline

Yamada K, Cirrito JR, Stewart FR, Jiang H, Finn MB, Holmes BB, Binder LI, Mandelkow EM, Diamond MI, Lee VM, Holtzman DM (2011) In vivo microdialysis reveals age-dependent decrease of brain interstitial fluid tau levels in P301S human tau transgenic mice. J Neurosci 31:13110-13117. CrossRef Medline

Yamada K, Holth JK, Liao F, Stewart FR, Mahan TE, Jiang H, Cirrito JR, Patel TK, Hochgräfe K, Mandelkow EM, Holtzman DM (2014) Neuronal activity regulates extracellular tau in vivo. J Exp Med 211:387-393. CrossRef Medline

Younan ND, Sarell CJ, Davies P, Brown DR, Viles JH (2013) The cellular prion protein traps Alzheimer's $A \beta$ in an oligomeric form and disassembles amyloid fibers. FASEB J 27:1847-1858. CrossRef Medline

Zempel H, Luedtke J, Kumar Y, Biernat J, Dawson H, Mandelkow E, Mandelkow EM (2013) Amyloid- $\beta$ oligomers induce synaptic damage via tau-dependent microtubule severing by TTLL6 and spastin. EMBO J 32: 2920-2937. CrossRef Medline

Zhang D, Qi Y, Klyubin I, Ondrejcak T, Sarell CJ, Cuello AC, Collinge J, Rowan MJ (2017) Targeting glutamatergic and cellular prion protein mechanisms of amyloid beta-mediated persistent synaptic plasticity disruption: longitudinal studies. Neuropharmacology 121:231-246. CrossRef Medline 